\title{
Use of Exopolysaccharide-Synthesizing Lactic Acid Bacteria and Fat Replacers for Manufacturing Reduced-Fat Burrata Cheese: Microbiological Aspects and Sensory Evaluation
}

\author{
Giuseppe Costantino, Maria Calasso, Fabio Minervini * (i) and Maria De Angelis \\ Department of Soil, Plant and Food Sciences, University of Bari Aldo Moro, Via Amendola 165/a, 70126 Bari, Italy; \\ giuseppecostant1989@libero.it (G.C.); maria.calasso@uniba.it (M.C.); maria.deangelis@uniba.it (M.D.A.) \\ * Correspondence: fabio.minervini@uniba.it; Tel.: +39-080-544-2946
}

Received: 21 September 2020; Accepted: 18 October 2020; Published: 21 October 2020

\begin{abstract}
This study aimed to set-up a biotechnological protocol for manufacturing a reduced-fat Burrata cheese using semi-skimmed milk and reduced-fat cream, in different combinations with exopolysaccharides-synthesizing bacterial starters (Streptococcus thermophilus, E1, or Lactococcus lactis subsp. lactis and Lc. lactis subsp. cremoris, E2) and carrageenan or xanthan. Eight variants of reduced-fat cheese (fat concentration 34-51\% lower than traditional full-fat Burrata cheese, used as the control) were obtained using: (i) semi-skimmed milk and reduced-fat cream alone (RC) or in combination with (ii) xanthan (RCX), (iii) carrageenan (RCC), (iv) starter E1 (RCE1), (v) starter E2 (RCE2), (vi) both starters (RCE1-2), (vii) E1 and xanthan (RCXE1), or E1 and carrageenan (RCCE1). Post-acidification occurred for the RCC, RCX, and RCE2 Burrata cheeses, due to the higher number of mesophilic cocci found in these cheeses after 16 days of storage. Overall, mesophilic and thermophilic cocci, although showing cheese variant-depending dynamics, were dominant microbial groups, flanked by Pseudomonas sp. during storage. Lactobacilli, increasing during storage, represented another dominant microbial group. The panel test gave highest scores to RCE1-2 and RCXE1 cheeses, even after 16 days of storage. The 16S-targeted metagenomic analysis revealed that a core microbiota (S. thermophilus, Streptococcus lutetiensis, Lc. lactis, Lactococcus sp., Leuconostoc lactis, Lactobacillus delbrueckii, and Pseudomonas sp.), characterized the Burrata cheeses. A consumer test, based on 105 people, showed that more than $50 \%$ of consumers did not distinguish the traditional full-fat from the RCXE1 reduced-fat Burrata cheese.
\end{abstract}

Keywords: reduced-fat cheese; Burrata cheese; fat replacers; exopolysaccharides-synthesizing lactic acid bacteria; characterization of microbiota; sensory analyses

\section{Introduction}

Burrata is a fresh "pasta filata" (i.e., stretched curd) cheese that originated in Apulia region at the beginning of nineteenth century [1]. To date, it is considered a specialty of Southern Italy, being produced, also, in Campania and Basilicata. Burrata cheese is included in the list of traditional agri-food products (Prodotto Agroalimentare Tradizionale (PAT) [2]. Moreover, a variety of Burrata, "Burrata di Andria", received the Protected Geographical Indication [3]. Burrata cheese is manufactured using pasteurized cow's milk, which is usually mixed with the acidified whey milk of the previous day's cheese-making process and added with calf rennet [4]. Once curd is obtained, a treatment with hot $\left(80-90^{\circ} \mathrm{C}\right)$ water allows stretching the curd. Then, the cheese is molded in its characteristic double structure, which consists of a "bag", made of stretched curd, and an inner creamy core, consisting of a 
mixture of strips of stretched curd ("sfilacci") and milk cream. Finally, the cheese is cooled down in chilled water [5].

Dairy products, including cheeses, provide nutrients to humans [6]. They are rich in proteins, lipids, many minerals (including $\mathrm{Ca}, \mathrm{Mg}, \mathrm{P}$, and $\mathrm{Zn}$ ) and vitamins (e.g., A, D, E, and K) [7]. Cheeses represent the main source of dietary Ca in many countries, especially USA, UK and Northern Europe [8,9]. Despite the important nutritional value of cheese, some researchers observed that its consumption increased in developing countries, whereas it showed a slight decline in developed countries [10]. This trend may be linked to the fact that a large dietary consumption of cheeses may play a negative role on health [11], because of the fat content, reaching high values (60\% of dry matter) in some varieties, such as Burrata [1]. Worldwide prevalence of obesity has been associated to the unbalance of dietary patterns (preference for high fat and sugar content food) and lifestyles [12]. Moreover, the combination of an unhealthy diet and factors, such as genetic background, smoking, and environmental pollution, leads to heart diseases and several types of cancers [13]. In particular, dietary fat has been linked with various breast, colorectal, pancreatic and prostate malignant cancers [14-17]. In addition, consumption of high fat and/or sugar induces a low-grade intestinal inflammation in animal model and leads to a change in the gut microbiota [12,18-20]. Furthermore, both a diet high in fat and obesity may have detrimental effects on sperm quality, resulting in a reduced mating and fertilization success [21]. Last, but not least, large intake of fat is directly linked to cardiovascular disease [22]. To date, the reduction of total dietary fat to less than $30 \%$ of total energy is recommended worldwide [23], including in countries where the Mediterranean diet is usually adopted [24].

Although numerous studies focused on strategies to reduce fat in cheese [25-28], commercial low-fat cheeses are perceived by consumers as excessively dry, firm, or difficult to chew, and with atypical flavor [26-29]. Indeed, fat positively affects the body, texture (e.g., palatability) and rheological properties of cheeses [30], by filling the interstitial spaces of casein network during curd coagulation, thus preventing the caseins from clumping too much [31-34]. Fat-replacers (e.g., carbohydrates, protein-, or fat-based compounds) increase the moisture content of low-fat cheeses and mimic the role of fat on sensory properties [27,35-38]. For instance, microparticulated whey proteins and starters producing exopolysaccharides (EPS) were used as fat replacers in Caciotta cheeses [39]. Trani et al. [1] suggested the use of a mixture of carob flour suspension and milk cream as ingredient of the inner core of Burrata cheeses. However, the resulting cheese, although acceptable, was perceived different from the full-fat cheese [1].

The aim of this work was to set-up a biotechnological protocol for manufacturing a reduced-fat Burrata cheese, sensorially indistinguishable from its traditional, full-fat, counterpart, with minimal modifications of the standard cheese-making processing. To this aim, different combinations of EPS-synthesizing lactic acid bacteria and natural fibers were tested as fat-replacers.

\section{Materials and Methods}

\subsection{Microorganisms}

Commercially available deep-frozen exopolysaccharide (EPS) producing starters, Cryofast ST440 and Cryofast MO342, were purchased from Clerici, Sacco S.r.l. (Cadorago, Como, Italy): Cryofast ST440 (alias E1) contains Streptococcus thermophilus, and Cryofast MO342 (alias E2) contains Lactococcus lactis subsp. lactis and Lc. lactis subsp. cremoris.

\subsection{Manufacturing of Burrata Cheese}

Whole milk (lactose $4.90 \%$, protein $3.70 \%$, fat $4.46 \%$, pH 6.6 , and cell density of total aerophilic microorganisms of ca. $4.3 \log \mathrm{CFU} \mathrm{g}{ }^{-1}$ ), supplied by Masseria Foggia Nuova (Noci, Bari, Italy), was treated through a Westfalia Separator MSB60-01-076 (GEA Group, Oelde, Germany) to obtain skimmed milk. Before being used, whole milk and skimmed milk were mixed in a ratio of 50:50 in order to obtain a semi-skimmed milk (ca $2.23 \%$ fat content). Subsequently, whole milk and semi-skimmed 
milk were pasteurized $\left(72{ }^{\circ} \mathrm{C}\right.$ for $\left.15 \mathrm{~s}\right)$ using a plate heat exchanger and then instantaneously cooled at $37-38{ }^{\circ} \mathrm{C}$. Milk was either directly acidified with lactic acid, reaching value of $\mathrm{pH}$ of ca. 5.90, or biologically acidified to $\mathrm{pH}$ of ca. 5.70 upon addition of E1 commercial starter. Three batches of milk were used for manufacturing as many batches of Burrata cheeses. No significant differences $(p>0.05)$ were observed among the three batches of milk, in terms of gross composition, $\mathrm{pH}$, and cell density of total aerophilic microorganisms.

Two types of powdered fat-replacers were used during manufacturing of four out of nine Burrata cheeses: (i) xanthan gum powder (99\% fiber purity) and (ii) carrageenan gum powder (99\% fiber purity), both purchased from Farmalabor S.r.l. (Canosa di Puglia, Barletta-Andria-Trani, Italy). Four types of milk cream were used for filling the inner core of Burrata cheese: (conventional) cream (28\% fat content), purchased from Cerri S.r.l. (Buronzo, Vercelli, Italy); reduced-fat cream (22\% fat content) (Cerri S.r.1.); reduced-fat cream diluted (60:40) with xanthan (0.5\% wt/vol) suspension (14\% fat content); reduced-fat cream diluted (60:40) with carrageenan $(1.0 \% w t / v o l)$ suspension (14\% fat content).

Nine types (including a control) of experimental Burrata cheeses were manufactured at the industrial plant Ignalat, located in Noci (Bari, Italy) (Table S1), namely: (1) cheese whose curd and "sfilacci" were obtained from whole milk, and whose core was constituted of "sfilacci" and cream (control); (2) cheese whose curd and "sfilacci" were obtained from semi-skimmed milk, and whose core was constituted of "sfilacci" and reduced-fat cream (RC); (3) cheese whose curd and "sfilacci" were obtained from semi-skimmed milk, and whose core was constituted of "sfilacci" and reduced-fat cream and xanthan (RCX); (4) cheese whose curd and "sfilacci" were obtained from semi-skimmed milk, and whose core was constituted of "sfilacci" and reduced-fat cream and carrageenan (RCC); (5) cheese whose curd and "sfilacci" were obtained from semi-skimmed milk inoculated with the starter E1 (6\% wt/vol), and whose core was constituted of "sfilacci" and reduced-fat cream (RCE1); (6) cheese whose curd and "sfilacci" were obtained from semi-skimmed milk, and whose core was constituted of "sfilacci" and reduced-fat cream inoculated with the starter E2 (3\% wt/vol) (RCE2); (7) cheese whose curd and "sfilacci" were obtained from semi-skimmed milk inoculated with the starter E1 (6\% wt/vol), and whose core was constituted of "sfilacci" and reduced-fat cream inoculated with the starter E2 (3\% wt/vol) (RCE1-2); (8) cheese whose curd and "sfilacci" were obtained from semi-skimmed milk inoculated with the starter E1 (6\% wt/vol), and whose core was constituted of "sfilacci" and reduced-fat cream and xanthan (RCXE1); (9) cheese whose curd and "sfilacci" were obtained from semi-skimmed milk inoculated with the starter E1 (6\% wt/vol), and whose core was constituted of "sfilacci" and reduced-fat cream and carrageenan (RCCE1). After manufacturing, all the cheeses were stored at $4{ }^{\circ} \mathrm{C}$ for 16 days.

\subsection{Compositional Analysis}

The Burrata cheeses were analyzed for the concentration of total carbohydrates, through highpressure liquid chromatography, and proteins, through Kjeldahl method, as described by Baldini et al. [40]. Fat content was determined using the van Gulik method [41]. Moisture was determined using Moisture Analyzer MA35 (Sartorius Stedim Biotech $\mathrm{GmbH}$, Germany). The $\mathrm{pH}$ value was measured by direct insertion of a FoodTrode Electrode (Hamilton, Bonaduz, Switzerland). Total titratable acidity (TTA) was determined on $10 \mathrm{~g}$ of sample, after homogenization with $90 \mathrm{~mL}$ of distilled water and expressed as the amount $(\mathrm{mL})$ of $0.1 \mathrm{M} \mathrm{NaOH}$ necessary to get $\mathrm{pH}$ of 8.3 .

\subsection{Assessment of Primary Proteolysis}

The $\mathrm{pH}$ 4.6-soluble and -insoluble nitrogen fractions of cheeses, obtained according to the method described by Kuchroo and Fox [42], were analyzed by denaturing urea polyacrylamide gel electrophoresis (urea-PAGE) [43], using sodium caseinate as standard reference. The gels were stained using Coomassie Brilliant blue G250 colorant, and destained according to Blakesley and Boezi [44]. Protein content of the $\mathrm{pH}$ 4.6-soluble and -insoluble nitrogen fractions of cheeses was evaluated 
spectrophotometrically by the Bradford method [45]. Concentration of peptides in the $\mathrm{pH}$ 4.6-soluble fraction was estimated by o-phthalaldehyde spectrophotometer method [46].

\subsection{Cultivable Microbiota}

Microbiological analyses were carried out as previously described by Minervini et al. [47] using culture media and supplements purchased from Oxoid (Basingstoke, UK). Ten grams of Burrata cheese were homogenized with $90 \mathrm{~mL}$ of sterile saline $\left(\mathrm{NaCl}, 9 \mathrm{~g} \mathrm{~L}^{-1}\right)$ in a 400P Bag Mixer $(3 \mathrm{~min}$ of treatment). Cell density of total mesophilic aerobic microorganisms was determined using plate count agar after incubation at $30{ }^{\circ} \mathrm{C}$. Presumptive mesophilic and thermophilic lactobacilli were enumerated using de Man, Rogosa and Sharpe (MRS) agar plates with the addition of cycloheximide $(0.1 \% \mathrm{wt} / \mathrm{vol})$ and incubated at $30^{\circ} \mathrm{C}$ and $45^{\circ} \mathrm{C}$, respectively. Presumptive mesophilic and thermophilic cocci were enumerated using lactose M17 agar plates with the addition of cycloheximide $(0.1 \% \mathrm{wt} / \mathrm{vol})$ and incubated at the same temperatures as for presumptive lactobacilli. Enterococci were counted after inoculating, by spreading technique, plates of Slanetz and Bartley agar and incubating at $37^{\circ} \mathrm{C}$. Staphylococci were determined inoculating, by spreading, plates of Baird Parker agar supplemented with egg yolk tellurite, and incubating at $37^{\circ} \mathrm{C}$. Total coliforms were counted on violet red bile glucose agar (VRBGA) after incubating plates at $37^{\circ} \mathrm{C}$. Plates of Pseudomonas agar, supplemented with cetrimide, fucidin, and cephalosporin (CFC) supplement, were spread inoculated with $0.1 \mathrm{~mL}$ of diluted sample and used to enumerate Pseudomonas spp. after incubation at $30^{\circ} \mathrm{C}$. Yeasts were enumerated on Sabouraud Dextrose Agar plates with the addition of chloramphenicol $(0.1 \% \mathrm{wt} / \mathrm{vol})$ and incubated at $25^{\circ} \mathrm{C}$. All plates were incubated for $48 \mathrm{~h}$, except for VRBGA and Pseudomonas agar, which were incubated for $24 \mathrm{~h}$.

\subsection{Sensory Analysis}

The sensory analysis of Burrata cheese was carried out using the method described by Coppola et al. [48] as modified by De Angelis et al. [49]. Ten volunteers ( 5 males and 5 females), with mean age of 30 years (range: $20-40$ years), were recruited from the laboratory staff. Three introductory sensory training sessions were held for discussing the sensory attributes with the panelists. Cheeses were taken out of the refrigerator $1 \mathrm{~h}$ before the sensory evaluation, and served at room temperature under normal (daylight) illumination. Each cheese (two pieces per thesis), identified by a code number, was given to each panelist on a single tray. Samples were served in a random order and evaluated in two replicates by all panelists. The quality attributes evaluated were governing liquid transparency, color, surface appearance, elasticity, sliminess, cream milk odor, fermented milk odor, acid taste, bitter taste, sweet taste, cream milk taste, salty taste, and aftertaste. Each sensory trait was rated with a score from 1 (lowest) to 5 (highest).

An additional sensory analysis, namely a consumer test, was implemented regarding the control and RCXE1 Burrata cheeses stored for 2 days at $4{ }^{\circ} \mathrm{C}$. One hundred and five people, who regularly consume fresh cheeses, were voluntarily recruited. All of the consumers tasted both the traditional full-fat (control) and the RCXE1 (reduced-fat) Burrata cheeses. Both the Burrata cheeses were labelled under different non-allusive codes, respectively " $A$ " for control and " $B$ " for RCXE1. Before the test, consumers were asked to fill in an evaluation form, which included several questions, such as age, educational qualification, job type, degree of knowledge of Burrata cheese, and purchasing and consumption habits. The sensory evaluation was conducted in a conference room where temporary partitions were erected to create one-consumer tasting booths, in order to reduce misperception and avoid crossed bias [50]. Each consumer was asked to distinguish, at first sight and taste, the traditional full-fat Burrata cheese from the reduced-fat one. Afterwards, the control and reduced-fat cheese were singly disclosed to each recruited consumer and consumer was asked to express compared judgment about appearance, texture, and odor, using one of the following phrases: (i) preference for control (Control); (ii) preference for reduced-fat cheese (RCXE1); (iii) no difference between the two cheeses 
(indifferent). Finally, consumers expressed the overall acceptability on a 0-10 point hedonic scale, taking into account appearance, texture, odor, and taste of Burrata cheeses.

\subsection{Extraction and Sequencing of Total Bacteria DNA}

Total DNA was extracted from Burrata cheese samples using FastDNA Spin Kit (MP Biomedicals, Solon, OH, USA) according to the manufacturer instructions. Quality and concentration of DNA was evaluated spectrophotometrically (NanoDrop ND-1000, Thermo Fisher Scientific, Inc., Waltham, MA, USA). DNA was used as template for 165 metagenomic analysis, which was carried out by Research and Testing Laboratory (RTL, Lubbock, TX, USA), using the Illumina MiSeq platform. A fragment of the 16S DNA gene for analysis of the diversity inside the domain of Bacteria was amplified using the primers 28F (GAGTTTGATCNTGGCTCAG) [51] and 519R (GTNTTACNGCGGCKGCTG) [52]. PCR and sequencing analyses were carried out according to the protocol of RTL. The sequenced reads were subsequently merged by PEAR Illumina paired-end merger and subsequently subjected to the USEARCH algorithm [53], which groups reads into clusters that include reads showing not more than $4 \%$ dissimilarity. Operational Taxonomic Units (OTUs) were selected by using the UPARSE OTU selection algorithm and the selected OTUs were chimera-checked using the UCHIME software, executed in de novo mode [54]. The percentage of each bacterial OTU was analyzed individually for each sample, providing relative abundance information among the samples, based on the relative numbers of reads within each [55].

\subsection{Statistical Analyses}

Data (at least three biological replicates) were subjected to one-way analysis of variance (ANOVA), and pair comparison of treatment means was achieved by Tukey's procedure at $p<0.05$, using the statistical software Statistica v. 7.0 for Windows. Principal Component Analysis (PCA) was also performed using Statistica v. 7.0. Spearman correlations for cell densities of microbial groups, OTUs, and biochemical characteristics of Burrata cheeses were computed using Statistica v. 7.0 and elaborated through PermutMatrix software.

\section{Results}

\subsection{Compositional Analysis}

After 1 day of manufacturing, all nine Burrata cheeses shared average values of total carbohydrates and proteins of $1.06 \pm 0.6 \mathrm{~g} / 100 \mathrm{~g}$ and $10.77 \pm 0.3 \mathrm{~g} / 100 \mathrm{~g}$, respectively. Control cheese (represented by traditional full-fat Burrata cheese) contained ca. $22 \%$ of fat (Table 1), whereas the Burrata cheeses obtained from semi-skimmed milk and reduced-fat cream, without adding xanthan or carrageenan in cheese core (RC, RCE1, RCE2, RCE1-2), contained on average $14.5 \%$ of fat, corresponding to ca. $34 \%$ in fat reduction. Burrata cheeses obtained from semi-skimmed milk and reduced-fat cream and with addition of xanthan or carrageenan (RCX, RCC, RCXE1, and RCCE1) showed an average fat concentration of $10.47 \%$, corresponding to ca. $51 \%$ in fat reduction. Moisture ranged between ca. $65 \%$ (control Burrata cheese) to ca. 75\% (RCXE1) (Table 1).

After 1 day of manufacturing, $\mathrm{pH}$ values ranged between $6.19 \pm 0.03(\mathrm{RC})$ and $6.46 \pm 0.03$ (RCC) (Figure 1A). After 8 and 16 days of storage, no statistically significant difference $(p>0.05)$ was found for RCE1-2, RCXE1, and RCCE1 cheeses. The $\mathrm{pH}$ of control Burrata cheese increased $(p<0.05)$ after 16 days of storage. The $\mathrm{pH}$ of RCE1 increased $(p<0.05)$ after 8 days, but showed no further variation $(p>0.05)$ after 16 days. With respect to day 1 , a significant decrease of $\mathrm{pH}$ was found after 16 days for RCX $(5.76 \pm 0.03)$, RCC $(5.83 \pm 0.03)$ and RCE2 $(5.85 \pm 0.03)$ Burrata cheeses. 
Table 1. Gross composition $(\mathrm{g} / 100 \mathrm{~g})$ *, determined after 1 day of manufacture, of the experimental Burrata cheeses ${ }^{\dagger}$.

\begin{tabular}{cccccc}
\hline Burrata Cheese Variant & Carbohydrates & Proteins & Total Fat & Moisture & Sodium \\
\hline Control & $1.2 \pm 0.06^{\mathrm{a}}$ & $10.4 \pm 0.03^{\mathrm{c}}$ & $21.6 \pm 0.05^{\mathrm{a}}$ & $65.4 \pm 0.90^{\mathrm{c}}$ & $0.50 \pm 0.02^{\mathrm{a}}$ \\
RC & $0.8 \pm 0.03^{\mathrm{b}}$ & $11.6 \pm 0.01^{\mathrm{a}}$ & $16.0 \pm 0.02^{\mathrm{b}}$ & $70.5 \pm 1.30^{\mathrm{b}}$ & $0.14^{\mathrm{a}} \pm .02^{\mathrm{c}}$ \\
RCX & $1.1 \pm 0.09^{\mathrm{a}}$ & $10.5 \pm 0.03^{\mathrm{bc}}$ & $10.0 \pm 0.05^{\mathrm{e}}$ & $72.0 \pm 1.40^{\mathrm{ab}}$ & $0.16 \pm 0.02^{\mathrm{bc}}$ \\
RCC & $1.2 \pm 0.06^{\mathrm{a}}$ & $10.0 \pm 0.01^{\mathrm{d}}$ & $10.6 \pm 0.03^{\mathrm{e}}$ & $71.5 \pm 1.20^{\mathrm{b}}$ & $0.20 \pm 0.02^{\mathrm{b}}$ \\
RCE1 & $0.8 \pm 0.05^{\mathrm{b}}$ & $11.0 \pm 0.03^{\mathrm{b}}$ & $13.0 \pm 0.05^{\mathrm{d}}$ & $70.3 \pm 1.40^{\mathrm{b}}$ & $0.14^{\mathrm{b}} \pm .03^{\mathrm{c}}$ \\
RCE2 & $1.0 \pm 0.05^{\mathrm{a}}$ & $11.2 \pm 0.02^{\mathrm{b}}$ & $14.5 \pm 0.04^{\mathrm{c}}$ & $70.4 \pm 1.20^{\mathrm{b}}$ & $0.20 \pm 0.01^{\mathrm{b}}$ \\
RCE1-2 & $1.1 \pm 0.06^{\mathrm{a}}$ & $11.0 \pm 0.01^{\mathrm{b}}$ & $14.5 \pm 0.05^{\mathrm{c}}$ & $72.3 \pm 1.40^{\mathrm{ab}}$ & $0.20 \pm 0.02^{\mathrm{b}}$ \\
RCXE1 & $1.2 \pm 0.05^{\mathrm{a}}$ & $10.6 \pm 0.01^{\mathrm{c}}$ & $11.0 \pm 0.04^{\mathrm{e}}$ & $75.7 \pm 1.20^{\mathrm{a}}$ & $0.16 \pm 0.03^{\mathrm{bc}}$ \\
RCCE1 & $1.2 \pm 0.07^{\mathrm{a}}$ & $10.6 \pm 0.03^{\mathrm{c}}$ & $11.5 \pm 0.05^{\mathrm{e}}$ & $73.6 \pm 1.20^{\mathrm{ab}}$ & $0.16 \pm 0.03^{\mathrm{bc}}$ \\
\hline
\end{tabular}

* Within the same column, values sharing one or more superscript letters (a-e) are not significantly $(p>0.05)$ different. ${ }^{\dagger}$ Control, cheese made from whole milk and cream; RC, cheese made from semi-skimmed milk and skimmed cream; RCX, cheese made from semi-skimmed milk and reduced-fat cream diluted with xanthan; RCC, cheese made from semi-skimmed milk and reduced-fat cream diluted with carrageenan; RCE1, cheese made from semi-skimmed milk added with exopolysaccharide producing starter E1 and reduced-fat cream; RCE2, cheese made from semi-skimmed milk, reduced-fat cream added with exopolysaccharide producing starter E2; RCE1-2, cheese made from semi-skimmed milk and reduced-fat cream both added with E1 and E2; RCXE1, cheese made from semi-skimmed milk added with E1 and reduced-fat cream diluted with xanthan; RCCE1, cheese made from semi-skimmed milk added with E1 and reduced-fat cream diluted with carrageenan.

A

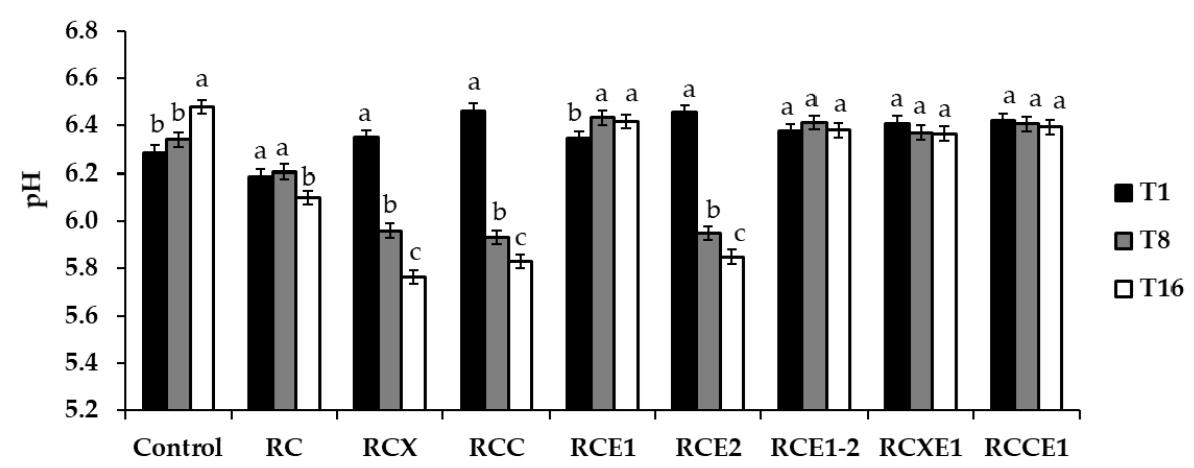

B

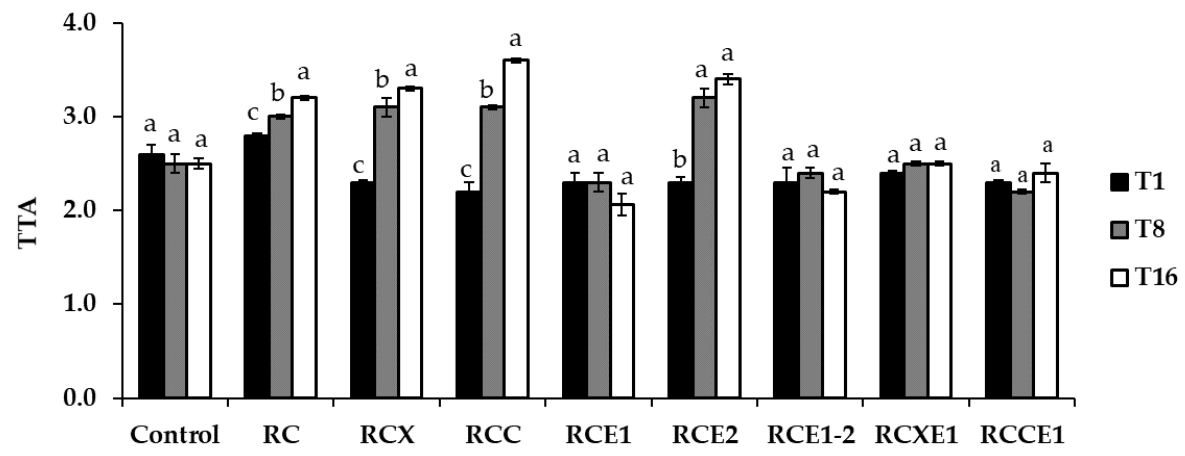

Figure 1. Values of $\mathrm{pH}(\mathrm{A})$ and total titratable acidity (TTA) (B), determined after 1 (T1), 8 (T8), and 16 (T16) days of storage at $4{ }^{\circ} \mathrm{C}$, in the Burrata cheeses made from whole milk and cream (Control); semi-skimmed milk and reduced-fat cream (RC); semi-skimmed milk and reduced-fat cream diluted with xanthan (RCX) or carrageenan (RCC); semi-skimmed milk added with exopolysaccharide producing starter E1 and reduced-fat cream (RCE1); semi-skimmed milk and reduced-fat cream added with exopolysaccharide producing starter E2 (RCE2); semi-skimmed milk and reduced-fat cream both added with E1 and E2 (RCE1-2); semi-skimmed milk added with E1 and reduced-fat cream diluted with xanthan (RCXE1) or carrageenan (RCCE1). Within the same thesis, bars labelled with the same letter represent not significantly $(p>0.05)$ different values. 
Total Titratable Acidity (TTA) ranged between $2.20 \pm 0.10$ and $2.80 \pm 0.10 \mathrm{~mL}$ of $\mathrm{NaOH} 0.1 \mathrm{M}$, after 1 day of storage. During storage, TTA increased $(p<0.05)$ in RC, RCX, RCC, and RCE2 Burrata cheeses, especially at 8 days. Overall, no differences $(p>0.05)$ were found in the other cheeses during storage (Figure 1B).

\subsection{Assessment of Proteolysis}

Limited hydrolysis of casein after 1 and 16 days of storage was found for $\mathrm{pH}$ 4.6-insoluble nitrogen fractions extracted from the Burrata cheeses, as assessed through urea polyacrylamide gel electrophoresis (urea-PAGE) (data not shown). At day 1, $\mathrm{pH}$ 4.6-insoluble fraction had a protein content higher than $11 \mathrm{~g} / \mathrm{kg}$ in all of the Burrata cheese variants, with slight differences among them (Figure 2A). After 16 days, the protein content generally decreased, with significant $(p<0.05)$ differences for all of the Burrata cheese variants, except for control and RC. At day 1, the concentration of proteins in the $\mathrm{pH}$ 4.6-soluble $\mathrm{N}$ fraction was ever higher than $0.7 \mathrm{~g} / \mathrm{kg}$ (Figure 2B). After 16 days, overall, the protein content increased, with significant $(p<0.05)$ differences for all of the Burrata cheese variants, except for RCE1-2 and RCCE1. Overall, the cheese variants obtained using E1 and/or E2 bacterial starters showed lower protein concentration (average value: $0.85 \mathrm{~g} / \mathrm{kg}$ ) in the soluble fraction than the other theses (average value: $1.22 \mathrm{~g} / \mathrm{kg}$ ). At 1 day, peptide concentration in the soluble fraction was $<300 \mathrm{mg} / \mathrm{kg}$ in RCX, RCC, whereas in the other Burrata cheese variants it ranged from ca. 310 (RCXE1) to ca. 450 (RCE1-2) mg/kg (Figure S1). After 16 days, peptides ranged from ca. 400 (RCC) to ca. 570 (RCE2) mg/kg. Except for the control, RCE1 and RCE1-2 Burrata cheeses, peptide concentration was higher $(p<0.05)$ than those found at 1 day.

\subsection{Cultivable Microbiota}

Culture-dependent microbiological analyses were carried out on all of the Burrata cheeses, after 1, 8 , and 16 days from manufacturing. Cell density of presumptive mesophilic lactobacilli ranged from $4.5 \log$ CFU g $^{-1}$ (RCXE1) to ca. $6.8 \mathrm{log}$ CFU g ${ }^{-1}$ (RCE1-2 Burrata cheese) after 1 day from manufacturing (Figure 3). During storage at $4{ }^{\circ} \mathrm{C}$, this bacterial group trended to increase, especially in RCE1 and RCXE1. The only exceptions were found for RCE1-2 and RCE2, which showed no variation $(p>0.05)$ or a decrease $(p<0.05)$, respectively, of the number of mesophilic lactobacilli. At 1 day, presumptive thermophilic lactobacilli varied from 4.0 (RCXE1) to 5.6 (RCCE1) log CFU g ${ }^{-1}$. During storage, they trended to increase in all of the Burrata cheeses, except for the control. After 16 days, this bacterial group ranged between 4.2 (control) and 6.8 (RC, RCE1-2, RCCE1, and RCXE1) $\log$ CFU g ${ }^{-1}$. At 1 day, presumptive mesophilic cocci varied from 6.1 (control) to 8.4 (RCE2) log CFU g ${ }^{-1}$. During storage, they showed different trends depending on the Burrata cheese variant: overall decrease (control); decrease at 8 days, followed by increase at 16 days (RC, RCX, RCC); no significant $(p>0.05)$ variations (RCE1, RCE2); overall increase (RCE1-2, RCXE1, RCCE1). At 1 day, presumptive thermophilic cocci ranged between 6.1 (control) and $8.3 \log \mathrm{CFU} \mathrm{g}^{-1}$ (RCX and RCE2). During storage, their trend was variable depending on the Burrata cheese variant: overall decrease (control and RCE2); decrease at 8 days, followed by increase at 16 days (RCX, RCC, RCCE1); increase at 8 days, followed by decrease at 16 days (RCE1-2); no significant ( $p>0.05$ ) variations (RCE1); steady increase (RC, RCXE1) (Figure 3).

Presumptive enterococci were found at relatively low cell densities in all of the Burrata cheeses and showed little variations during storage. On average, values were ca. 4.7, 4.3 and $4.5 \log \mathrm{CFU} \mathrm{g}^{-1}$, after 1, 8 and 16 days, respectively. After 1 day of manufacturing, total mesophilic microorganisms ranged between $5.3 \log \mathrm{CFU} \mathrm{g}^{-1}$ (control) and $8.1 \mathrm{log} \mathrm{CFU} \mathrm{g}^{-1}$ (RCX). They trended to increase in control, RCC, RCE1, RCXE1, and RCCE1, whereas they trended to decrease in RC, RCX, and RCE1-2 Burrata cheeses. At 1 day, presumptive staphylococci were detected at cell densities ranging from 3.3 (RCC) to 4.6 (RC and RCCE1) $\log \mathrm{CFU} \mathrm{g}^{-1}$. After 8 days, they were not detectable in RC, RCE1, RCE1-2, and control Burrata cheeses, but persisted at an average value of ca $3.5 \log \mathrm{CFU} \mathrm{g}^{-1}$ in the other cheese variants. Staphylococci were absent after 16 days in all of the cheeses. Total coliforms were not found in control and RCE1 cheeses at 1 day of manufacturing and ranged between 2.0 (RCE1-2) to 
4.2 (RCE2) $\log \mathrm{CFU} \mathrm{g}{ }^{-1}$ for the other Burrata cheeses. They overall increased $(p<0.05)$ during storage at $4{ }^{\circ} \mathrm{C}$, with final values ranging between 3.1 (control) and 5.1 (RCXE1) $\log \mathrm{CFU} \mathrm{g}{ }^{-1}$. The only exception was RCX, wherein coliforms showed no significant $(p>0.05)$ variation. Presumptive Pseudomonas sp. was found at average cell density of $4.0 \log \mathrm{CFU} \mathrm{g}{ }^{-1}$ at 1 day of storage time. During storage, overall, they increased and were detected at cell densities between ca. 6.3 (RCE1-2) and 7.4 (RCX) log CFU g ${ }^{-1}$ (Figure 3).

A

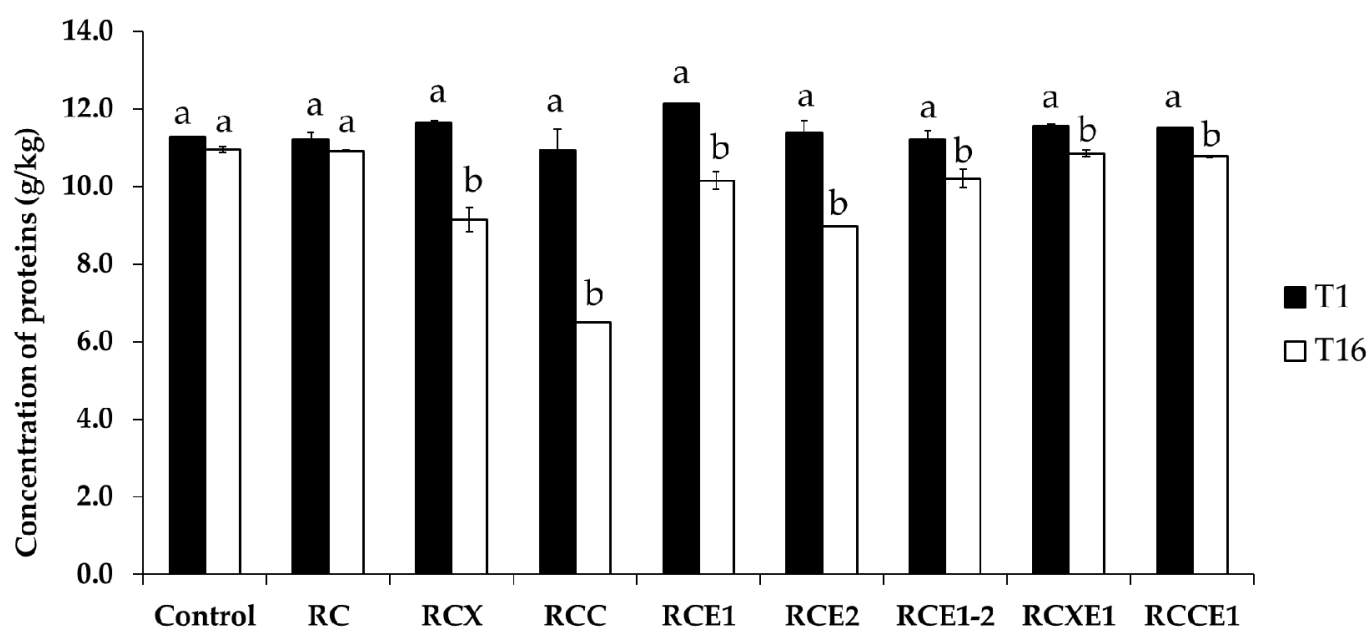

B

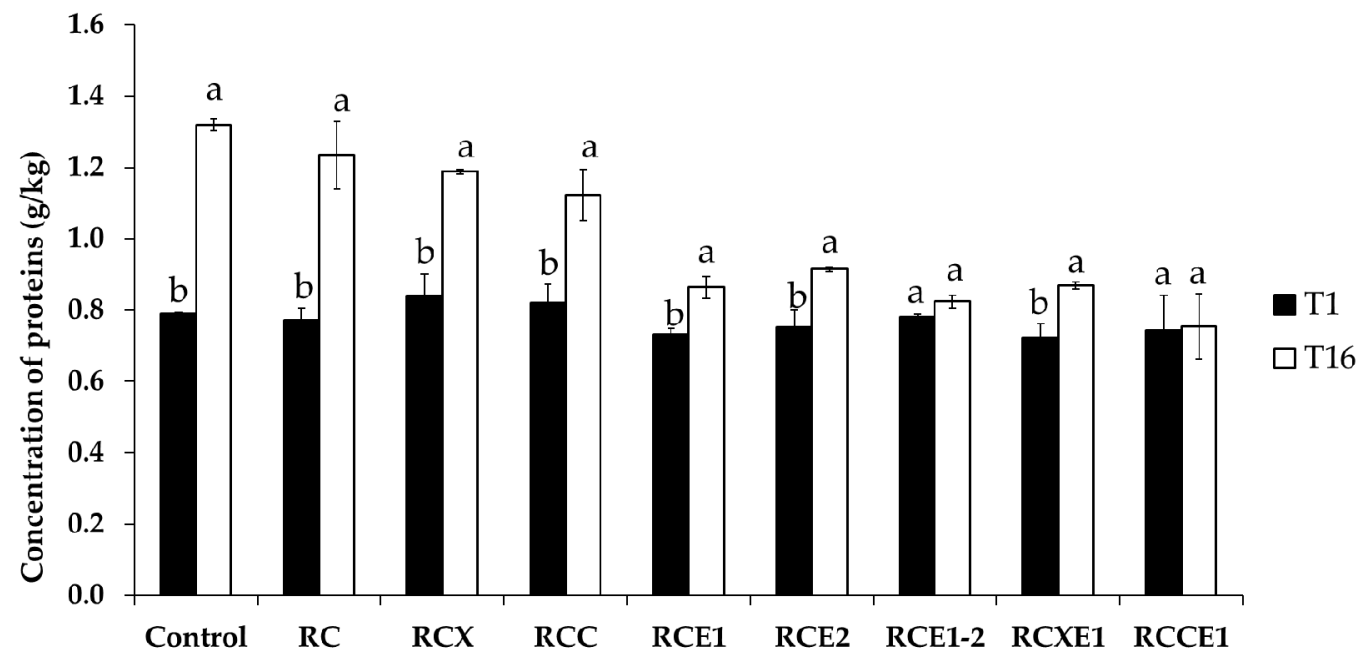

Figure 2. Concentration of proteins in the $\mathrm{pH}$ 4.6-insoluble (A) and $\mathrm{pH}$ 4.6-soluble nitrogen fraction (B), determined after 1 (T1) and 16 (T16) days of storage at $4{ }^{\circ} \mathrm{C}$, in the Burrata cheeses made from whole milk and cream (Control); semi-skimmed milk and reduced-fat cream (RC); semi-skimmed milk and reduced-fat cream diluted with xanthan (RCX) or carrageenan (RCC); semi-skimmed milk added with exopolysaccharide producing starter E1 and reduced-fat cream (RCE1); semi-skimmed milk and reduced-fat cream added with exopolysaccharide producing starter E2 (RCE2); semi-skimmed milk and reduced-fat cream both added with E1 and E2 (RCE1-2); semi-skimmed milk added with E1 and reduced-fat cream diluted with xanthan (RCXE1) or carrageenan (RCCE1). Within the same thesis, bars labelled with the same letter represent not significantly $(p>0.05)$ different values.

No molds were detectable after 1, 8, and 16 days of storage in all of the Burrata cheese variants (data not shown). Yeasts were not found in the control at 1 day of manufacturing, whereas in the other variants they ranged from 2.2 (RCE1-2) to 4.4 (RCX) log CFU g ${ }^{-1}$. During storage, yeasts increased in all of the Burrata cheese variants, with the exceptions of RC and RCC, wherein they remained constant or decreased, respectively (Figure 3 ). 


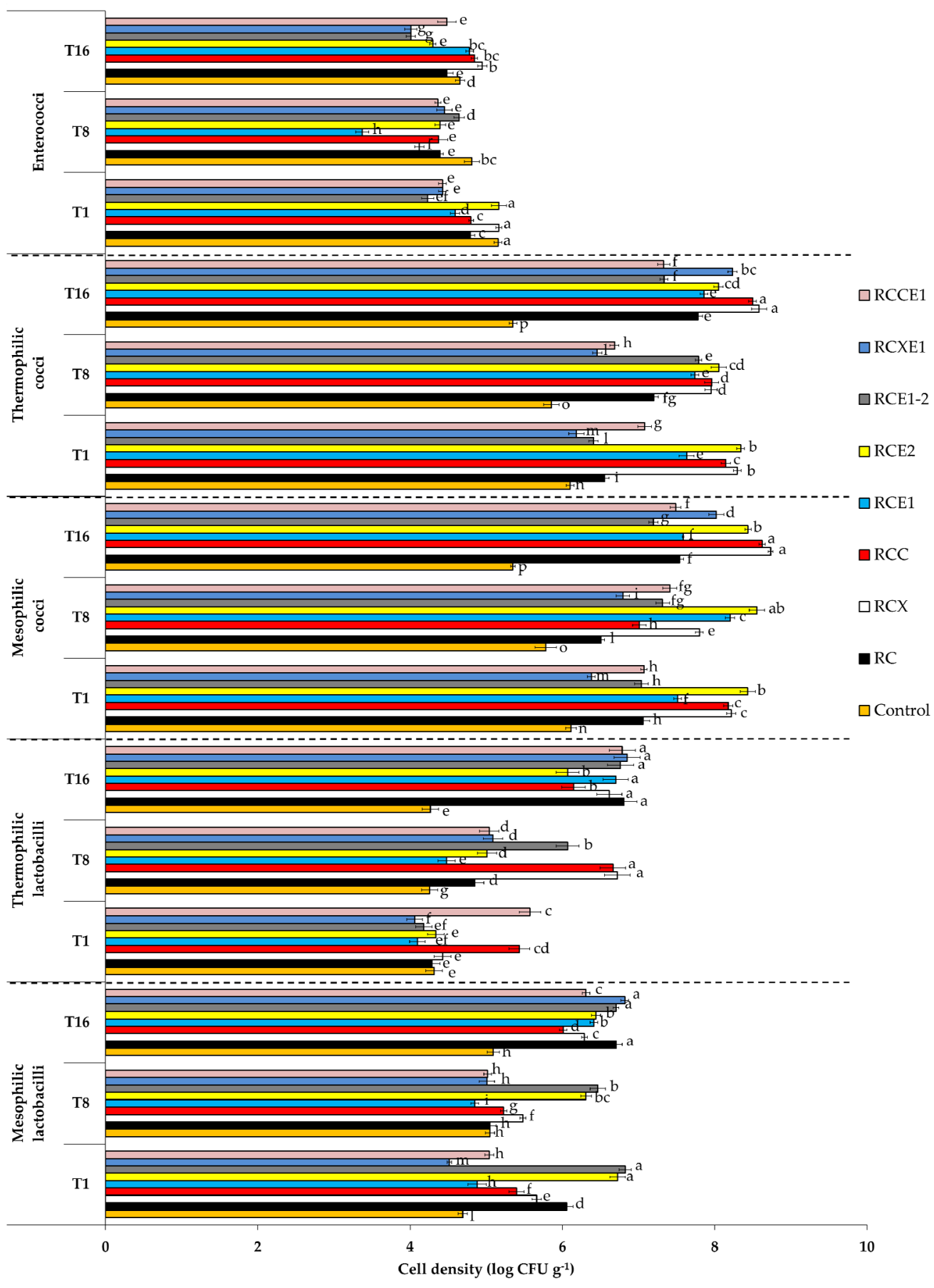

Figure 3. Cont. 


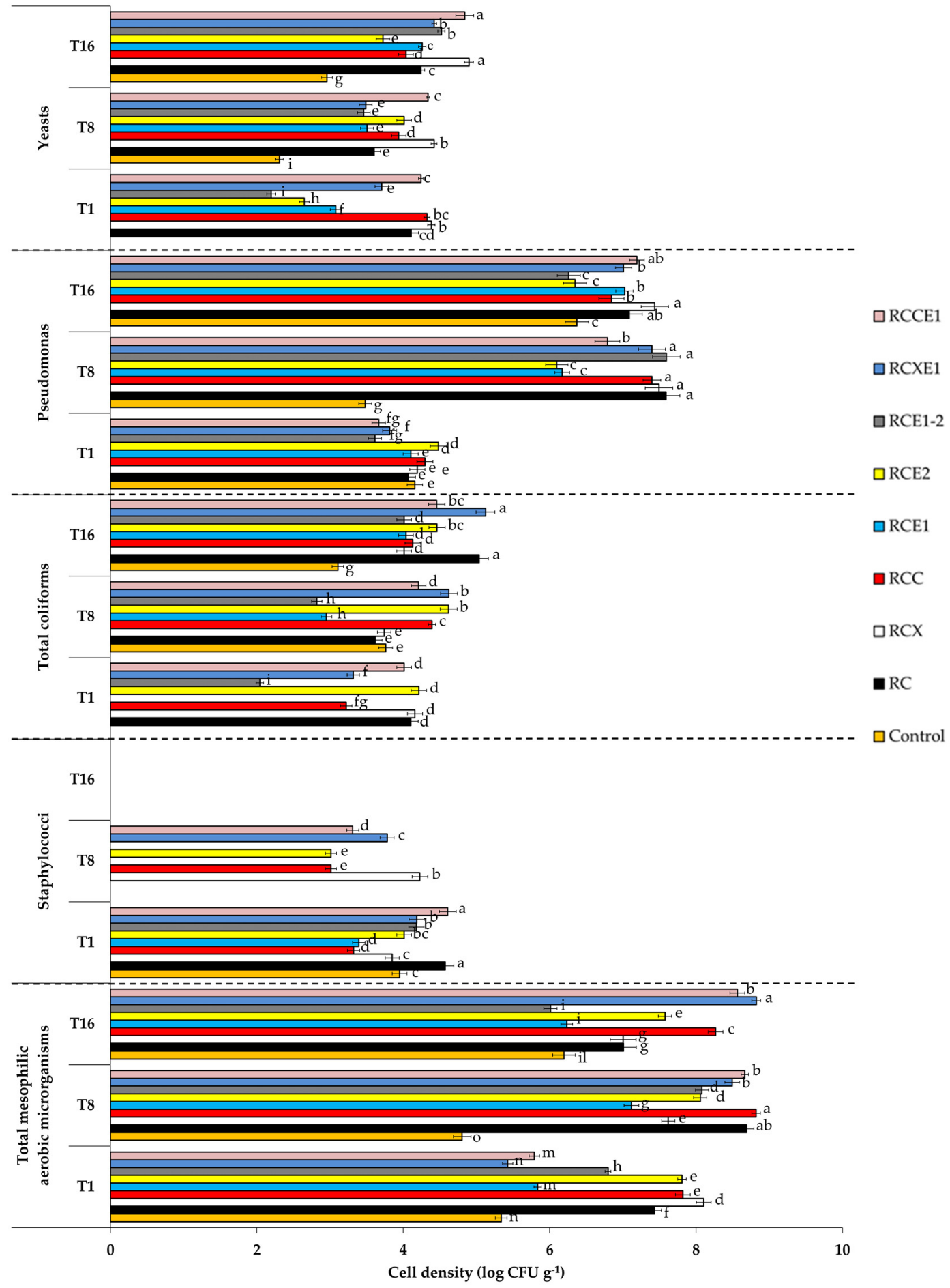

Figure 3. Cell densities of microbial groups, determined after 1 (T1), 8 (T8), and 16 (T16) days of storage at $4{ }^{\circ} \mathrm{C}$, in the Burrata cheeses made from whole milk and cream (Control); semi-skimmed milk and reduced-fat cream (RC); semi-skimmed milk and reduced-fat cream diluted with xanthan (RCX) or carrageenan (RCC); semi-skimmed milk added with exopolysaccharide producing starter E1 and reduced-fat cream (RCE1); semi-skimmed milk and reduced-fat cream added with exopolysaccharide producing starter E2 (RCE2); semi-skimmed milk and reduced-fat cream both added with E1 and E2 (RCE1-2); semi-skimmed milk added with E1 and reduced-fat cream diluted with xanthan (RCXE1) or carrageenan (RCCE1). Within the same panel (showing a given microbial group), bars labelled with one or more common letters represent not significantly $(p>0.05)$ different values. 


\subsection{Panel Test}

All of the Burrata cheeses were subjected to a panel test, after 1, 8, and 16 days from manufacturing. After 1 day, RCE1, RCE1-2, and RCXE1 Burrata cheeses received average scores (on a 5-points scale) higher than 4 for overall acceptability (Figure 4). This attribute ranged between 3.2 and 3.8 for RC, RCX, RCCE1, and control cheeses. After 8 days, overall acceptability ranged from 2.8 (RCX) to 4.0 (RC, RCE1, RCE1-2). After 16 days, the highest $(p<0.05)$ score was attributed to RCE1-2 (4.2 on average). Scores of 3.9 and 3.5 were attributed to RCXE1 and RCCE1 Burrata cheeses for overall acceptability (Figure 4).

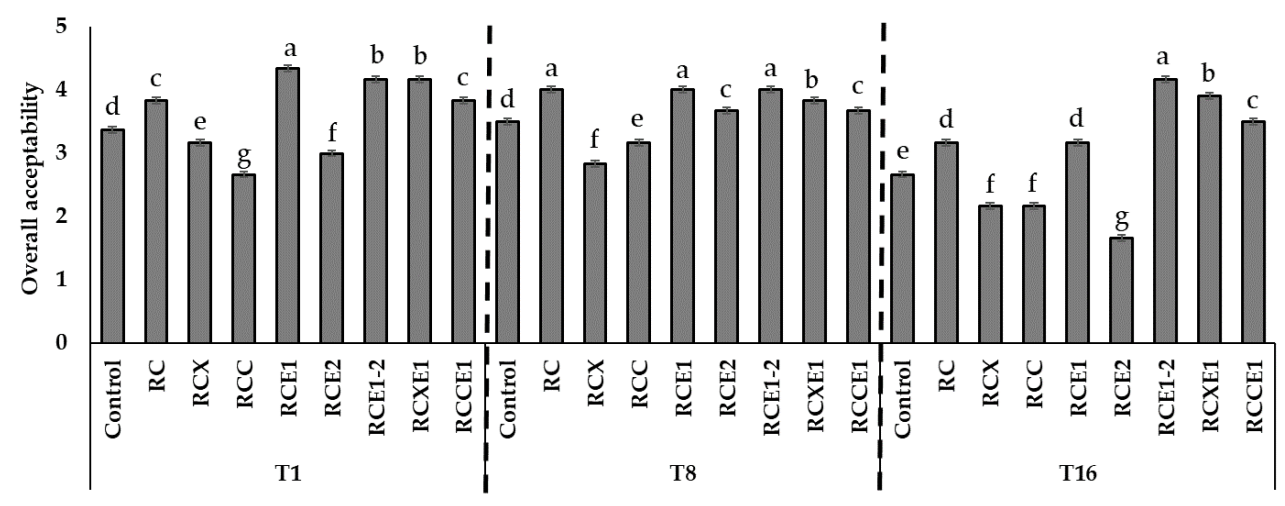

Figure 4. Average values of overall acceptability evaluated through panel test, carried out after 1 (T1), 8 (T8), and 16 (T16) days of storage at $4{ }^{\circ} \mathrm{C}$ on the Burrata cheeses made from whole milk and cream (Control); semi-skimmed milk and reduced-fat cream (RC); semi-skimmed milk and reduced-fat cream diluted with xanthan (RCX) or carrageenan (RCC); semi-skimmed milk added with exopolysaccharide producing starter E1 and reduced-fat cream (RCE1); semi-skimmed milk and reduced-fat cream added with exopolysaccharide producing starter E2 (RCE2); semi-skimmed milk and reduced-fat cream both added with E1 and E2 (RCE1-2); semi-skimmed milk added with E1 and reduced-fat cream diluted with xanthan (RCXE1) or carrageenan (RCCE1). Within the same time of analysis, bars labelled with the same letter represent not significantly $(p>0.05)$ different values.

The results of the other attributes (governing liquid transparency, color, surface appearance, elasticity, sliminess, cream milk odor, fermented milk odor, acid taste, bitter taste, sweet taste, cream milk taste, salty taste, and aftertaste) evaluated through the panel test are shown in Table S2 and were elaborated through Principal Component Analysis (PCA) (Figure 5). Regardless of time of analysis, two first components explained at least $63.06 \%$ of total variance. At 1 day, the negative segment of PC1 showed the loading of surface appearance (Surf), whereas the positive segment showed the loading of creamy (CreamOd) and fermented (FermOd) odors, and bitter taste. Sweet and salty taste showed the highest positive and negative, respectively, loads for PC2. The cheese variants were distributed in two groups: RC, RCE1, RCXE1, RCCE1, RCE1-2, and control Burrata cheeses fell in the left quadrants of the plane; the other variants fell in the right quadrants. Within the first group, the control showed many sensory differences, reporting the highest scores for salty taste and color. RCE1-2 was particularly appreciated for its good surface appearance (Figure 5A).

After 8 days of storage, the negative segment of $\mathrm{PC} 1$ showed the loading of sweet taste, whereas the positive segment showed the loading of bitter and acid tastes. Aftertaste and elasticity (Ela) showed the highest negative and positive, respectively, loads for PC2. Again, RC, RCE1, RCXE1, RCCE1, and RCE1-2 Burrata cheeses fell in the left quadrants of the plane, whereas the control and the other Burrata cheeses fell in the right quadrants. However, the group of cheeses in the right quadrants included two Burrata cheeses (RCC and RCX), judged as very similar, characterized by being bitter, acid and with a strong fermented milk odor. On the contrary, the two other Burrata cheese variants (control and RCE2) showed quite different sensory traits both each other and with respect to RCC and RCX (Figure 5B). 
A
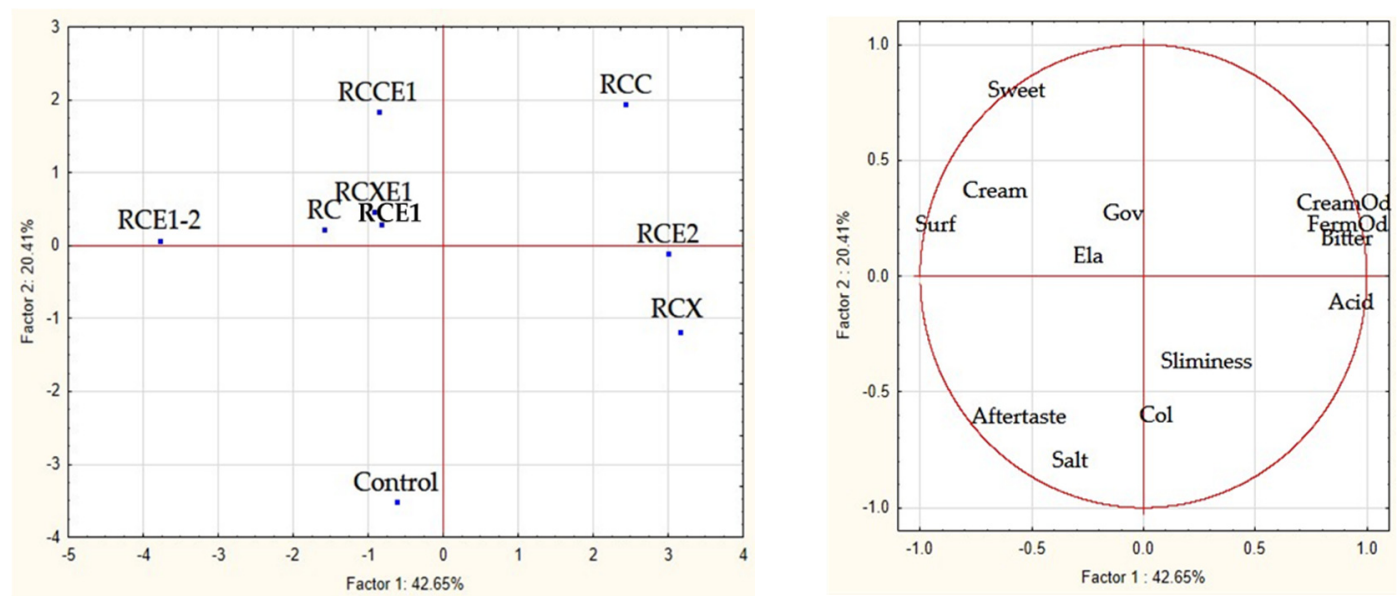

B
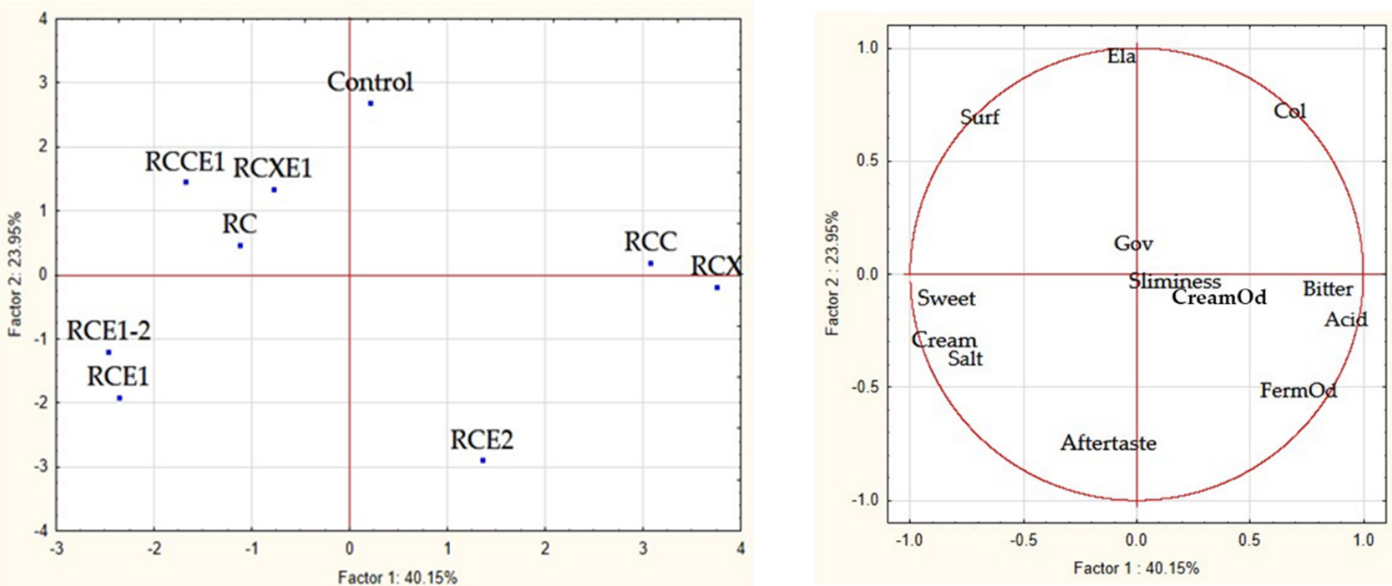

C
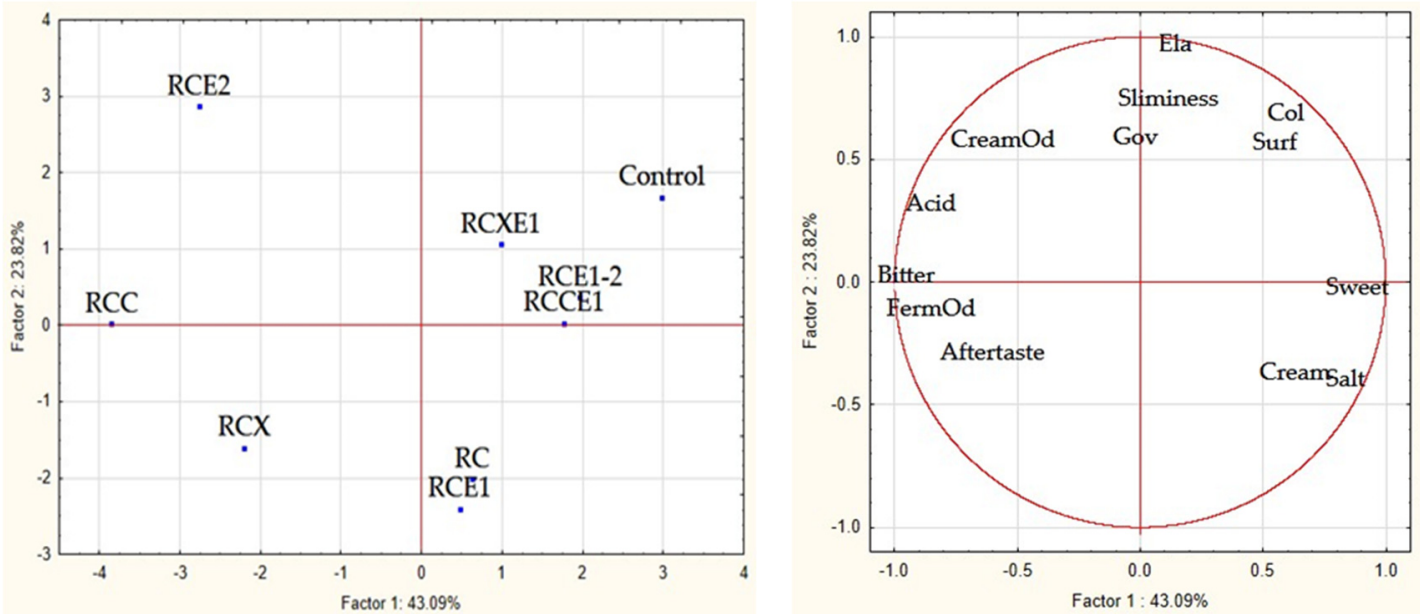

Figure 5. Scores and loading plots of the first and second principal components after Principal Component Analysis (PCA) based on the sensory attributes evaluated through panel test. (A) PCA carried out after 1 day; (B) PCA carried out after 8 days; (C) PCA carried out after 16 days of storage at $4{ }^{\circ} \mathrm{C}$ of the Burrata cheeses made from whole milk and cream (Control); semi-skimmed milk and reduced-fat cream (RC); semi-skimmed milk and reduced-fat cream diluted with xanthan (RCX) or carrageenan (RCC); semi-skimmed milk added with exopolysaccharide producing starter E1 and reduced-fat cream (RCE1); semi-skimmed milk and reduced-fat cream added with exopolysaccharide producing starter E2 (RCE2); semi-skimmed milk and reduced-fat cream both added with E1 and E2 (RCE1-2); semi-skimmed milk added with E1 and reduced-fat cream diluted with xanthan (RCXE1) or carrageenan (RCCE1). 
After 16 days, the negative segment of PC1 showed the loading of bitter taste and fermented milk odor, whereas the positive segment showed the loading of sweet taste. Elasticity showed the highest positive load for PC2. RCCE1, RCXE1, RCE1-2, and control Burrata cheeses grouped in the fourth quadrant of the plane, being evaluated as sweet and elastic. RC and RCE1 fell in the third quadrant, whereas RCE2, RCX, and RCC fell in the first, second and at borderline between first and second quadrant, respectively. Bitter and acid taste and strong unpleasant aftertaste characterized RCE2, RCX, and RCC Burrata cheeses (Figure 5C).

\subsection{Burrata Microbiome}

In order to understand the potential role of bacterial community in the sensory traits, the following four Burrata cheese variants were selected for analysis of bacterial microbiome after 1 and 16 days of storage: RCXE1 and RCE1-2, being the most preferred (based on the results from the panel test) Burrata cheeses; RC, being a reduced-fat cheese, exactly as RCXE1 and RCE1-2, but without additional EPS-producing starters and xanthan or carrageenan; control, being the traditional full-fat Burrata cheese. At 1 day, Streptococcus thermophilus was the most abundant bacterial species in the control, RC and RCE1-2 Burrata cheeses (Figure 6, Table S3). In the control, this Operational Taxonomic Unit (OTU) (relative abundance: $51.8 \%$ ) was flanked by Streptococcus lutetiensis (23.9\%), Lactobacillus delbrueckii $(16.7 \%)$ and Lactococcus lactis (3.6\%). RC Burrata cheese harbored, besides S. thermophilus (65\%), Lc. lactis $(10.8 \%)$, Leuconostoc lactis (10.5\%), and, as minor OTUs, Lactobacillus delbrueckii (1.3\%) and Moraxella osloensis (1.7\%). In RCE1-2 Burrata cheese, besides S. thermophilus (88.3\%), Lc. lactis (8.1\%) was detected as sub-dominant. RCXE1 Burrata cheese harbored Pseudomonas sp. (39.7\%) and Bacilli $(36.5 \%)$ as dominant OTUs, and Lactococcus sp. (6.9\%), Leuconostoc mesenteroides (6.1\%), and S. thermophilus (3\%) as sub-dominant/minor OTUs (Figure 6, Table S3).

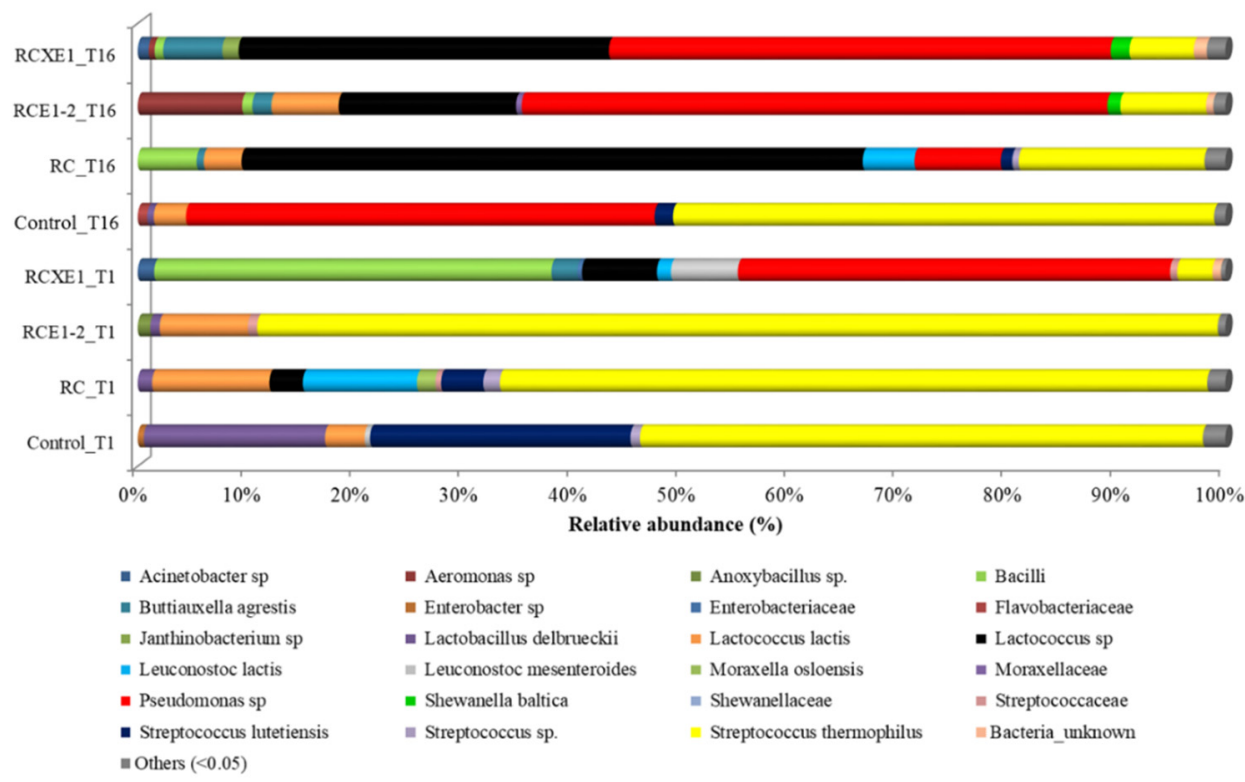

Figure 6. Relative abundance (\%) of the main bacterial Operational Taxonomic Units (OTUs) assigned at the highest possible taxonomic level found after 1 (T1) and 16 (T16) days of storage at $4{ }^{\circ} \mathrm{C}$, in the Burrata cheeses made from: whole milk and cream (Control); semi-skimmed milk and reduced-fat cream (RC); semi-skimmed milk and reduced-fat cream both added with E1 and E2 (RCE1-2); semi-skimmed milk added with E1 and reduced-fat cream diluted with xanthan (RCXE1). "Others" represent OTUs found at relative abundance less than $0.05 \%$. 
After 16 days of storage, S. thermophilus was still the dominant OTU (relative abundance: 49.7\%) in the control cheese, but it was flanked by Pseudomonas sp. (43.1\%). The control Burrata cheese also harbored Lc. lactis (3\%) and S. lutetiensis $(1.7 \%)$ as sub-dominant OTUs. RC harbored Lactococcus sp. (57.1\%), S. thermophilus (17.1\%), Pseudomonas sp. (7.9\%), Leuc. lactis (4.8\%), Bacilli (5.4\%), and Lc. lactis (3.5\%). RCXE1 and RCE1-2 showed quite a similar profile of bacterial biota, with dominance of Pseudomonas sp. (46.1-53.9\%), followed by Lactococcus sp. (14-34\%) and S. thermophilus (5.9-7.9\%). These two Burrata cheeses shared also some less abundant OTUs, such as Shewanella baltica and Bacilli. The only differences found in these cheeses were for Aeromonas sp. and Buttiauxella agrestis, found in RCE1-2 at higher and lower (respectively) relative abundance than in RCXE1 (Figure 6, Table S3).

\subsection{Correlations between Microbiota and Biochemical Characteristics of Burrata Cheeses}

Results from microbiological (cell densities of all of the microbial groups, relative abundance of bacterial OTUs) and biochemical characterization ( $\mathrm{pH}$, TTA, concentrations of proteins and peptides in the cheese extracts) of the two most preferred reduced-fat Burrata cheeses (RCXE1 and RCE1-2), of the reduced-fat cheese RC, and of the traditional full-fat Burrata cheese (control) were elaborated through PCA, in order to better estimate the influence of variables on the quality of cheeses (Figure 7). At day 1, RCE1-2 and RC Burrata cheeses were clearly differentiated from RCXE1 and control Burrata cheeses (Figure 7A). The two latter cheeses were also separated one from each other. After 16 days of storage, all of the reduced-fat Burrata cheeses fell in the third quadrant of the plane, thus being clearly differentiated from all of the other cheeses, including the control analyzed at 16 days. Among the variables, thermophilic lactobacilli and enterococci showed high positive and negative loadings on PC1, respectively (Figure 7B).

Several negative $(r<-0.7)$ and positive $(r>0.7)$ correlations between variables were found (Figure S2). For instance, $\mathrm{pH}$ was negatively correlated with Leuc. lactis and Streptococcus sp. S. thermophilus was negatively correlated with the OTUs Enterobacteriaceae and Pseudomonas sp. and positively with Lc. lactis. Positive correlations were found between Macrococcus caseolyticus and Streptococcus sp., Streptococcus parauberis, Leuc. lactis, and Lc. lactis. Cell densities of thermophilic lactobacilli were negatively correlated with enterococci and staphylococci.

A

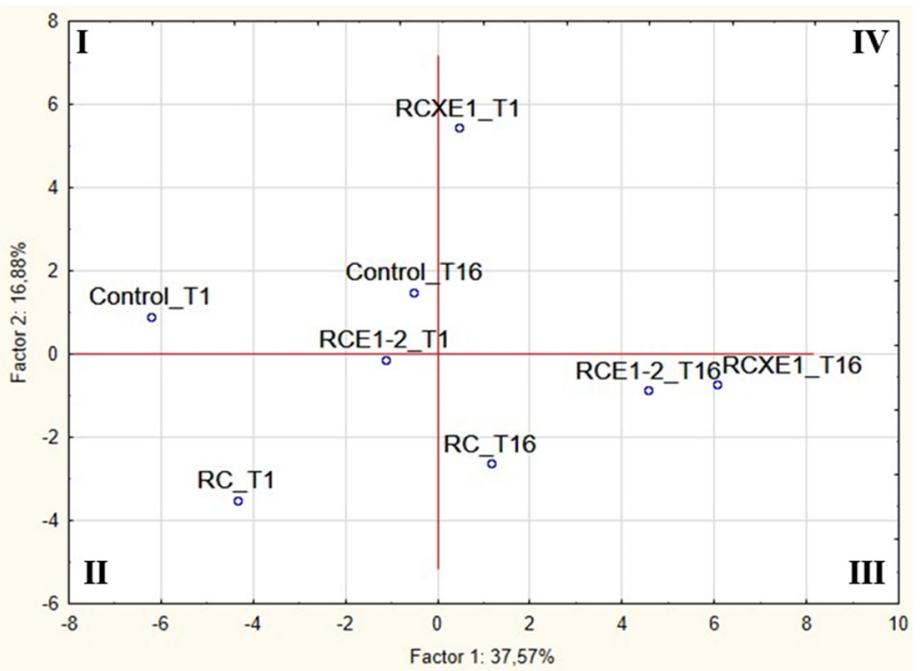

Figure 7. Cont. 


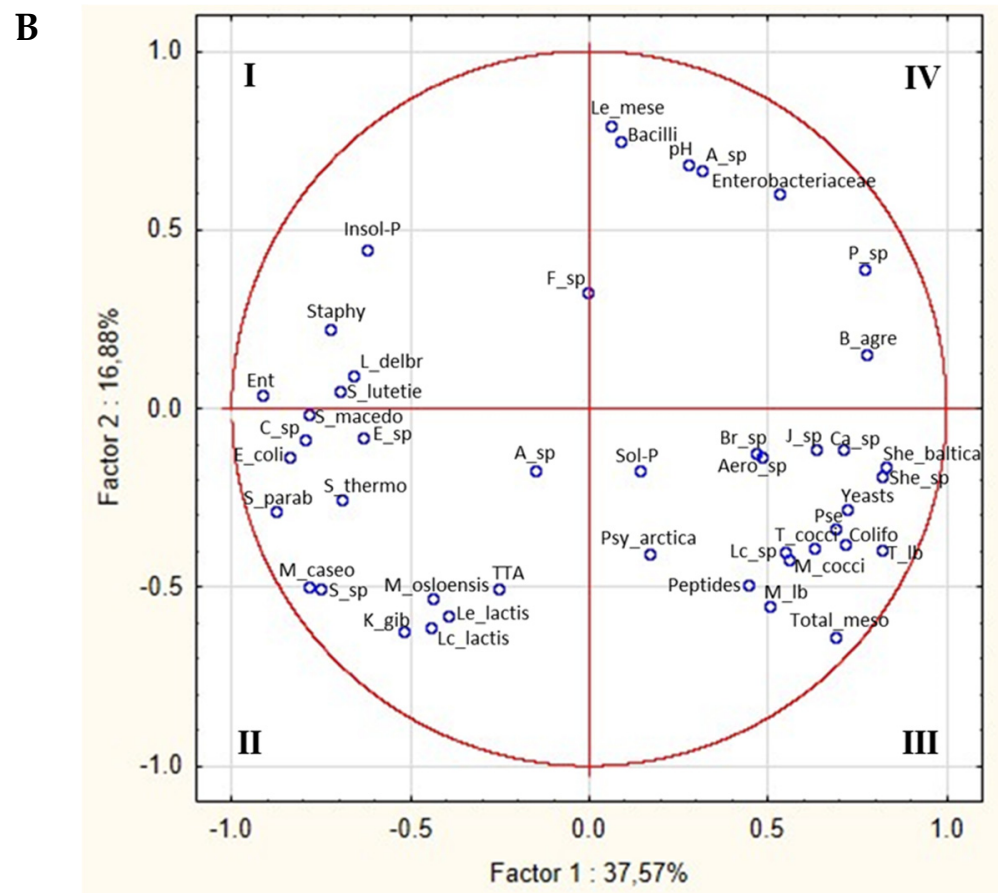

Figure 7. Scores (A) and loading (B) plots of first and second principal components after Principal Component Analysis based on microbiological (cell densities, OTU relative abundance) and biochemical $(\mathrm{pH}, \mathrm{TTA}$, concentrations of proteins in $\mathrm{pH}$ 4.6-soluble and -insoluble fraction, concentration of peptides in $\mathrm{pH}$ 4.6-soluble fraction) characteristics determined after 1 (T1) and 16 (T16) days of storage at $4{ }^{\circ} \mathrm{C}$ on the Burrata cheeses made from: whole milk and cream (Control); semi-skimmed milk and reduced-fat cream (RC); semi-skimmed milk and reduced-fat cream both added with E1 and E2 (RCE1-2); semi-skimmed milk added with E1, and reduced-fat cream diluted with xanthan (RCXE1). Total titratable acidity, TTA; total mesophilic microorganisms, Total_meso; mesophilic lactobacilli, M_lb; thermophilic lactobacilli, T_lb; mesophilic cocci, M_cocci; thermophilic cocci, T_cocci; enterococci, Ent; presumptive Pseudomonas sp., Pse; staphylococci, Staphy; coliforms, Colifo; proteins in insoluble fraction, Inso-P; proteins in soluble fraction, Sol-P; Chryseobacterium sp., C_sp; Flavobacterium sp., F_sp; Anoxybacillus sp., A_sp; Brochothrix sp., Br_sp; Kurthia gibsonii, K_gib; Macrococcus caseolyticus, M_caseo; Carnobacterium sp., Ca_sp; Lactobacillus delbrueckii, L_delbr; Leuconostoc lactis, Le_lactis; Leuconostoc mesenteroides, Le_mese; Lactococcus lactis, Lc_lactis; Lactococcus sp., Lc_sp; Streptococcus lutetiensis, S_lutetie; Streptococcus macedonicus, S_macedo; Streptococcus parauberis, S_parab; Streptococcus thermophilus, (S_thermo); Streptococcus sp. (S_sp); Janthinobacterium sp., J_sp; Aeromonas sp., Aero_sp; Psychromonas arctica, Psy_arctica; Shewanella baltica, She_baltica; Buttiauxella agrestis, B_agre; Enterobacter sp., E_sp; Escherichia coli, E_coli; Acinetobacter sp., A_sp; Moraxella osloensis, M_osloensis; Pseudomonas sp., P_sp.

\subsection{Consumer Test}

RCXE1 was subjected, along with control Burrata cheese, to a consumer test, because it contained fat concentration lower (ca. 50\%) than the control and had been (together with RCE1-2) the most preferred cheese, on the basis of the results from the panel test. Among the consumers participating in the test, most $(92.7 \%)$ were occasional consumers of Burrata cheese, whereas the remaining $7.3 \%$ declared to eat Burrata at least once a week. The data processing highlighted that $53.7 \%$ of the consumers did not distinguish, at first sight and taste, the reduced-fat Burrata cheese (RCXE1) from the control. After disclosure of the Burrata cheese variants, although $48 \%$ of consumers preferred the control in terms of appearance, $23 \%$ preferred the reduced-fat Burrata cheese, and 29\% did not perceive any difference between the two cheese variants (Figure $8 \mathrm{~A}$ ). In terms of texture, 51\% of consumers preferred the control, $42 \%$ preferred the reduced-fat cheese, and $7 \%$ perceived the two cheese as not 
different (Figure $8 \mathrm{~B}$ ). In regards to odor, $40 \%$ of participants preferred the traditional Burrata cheese, $26 \%$ preferred the reduced-fat Burrata cheese, and $34 \%$ did not perceive any difference (Figure $8 \mathrm{C}$ ). Lastly, the average acceptability scores were $8.0 \pm 0.80$ for traditional Burrata cheese and 7.0 \pm 1.40 for RCXE1 reduced-fat Burrata.

A

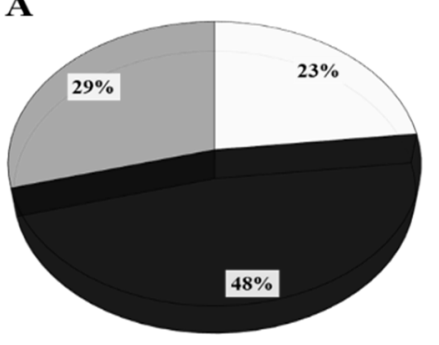

B

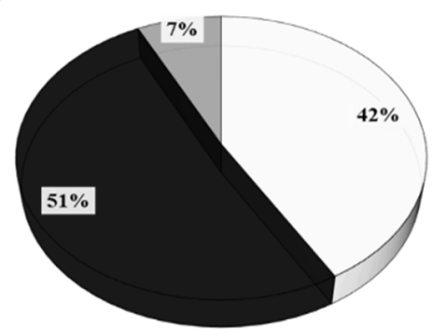

C

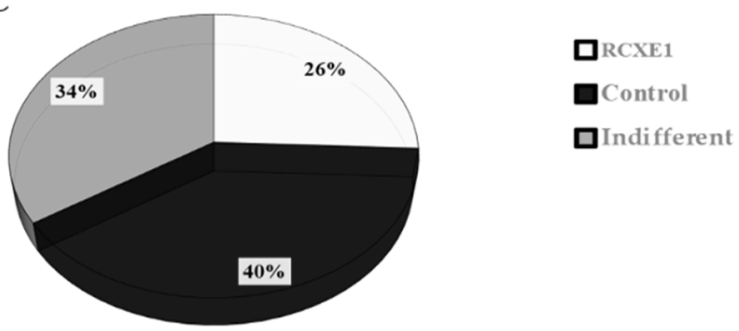

Figure 8. Percentages of consumers expressing compared judgment about appearance (A), texture (B), and odor (C) between the traditional full-fat Burrata cheese (Control) and the reduced-fat Burrata cheese produced from semi-skimmed milk added with E1 and reduced-fat cream diluted with xanthan (RCXE1). Compared judgment was expressed using one of the following phrases: (i) preference for Control; (ii) preference for RCXE1; (iii) no difference between the two cheeses (indifferent).

\section{Discussion}

Reduction of dietary fat intake is one of the main recommendations by the World Health Organization (WHO) [56-58]. Cheeses are among the main vehicles of dietary fat but, at the same time, represent a frequent and pleasant dietary choice for many consumers [59,60]. Therefore, more and more cheesemakers and researchers are interested in strategies to produce low-fat or reduced-fat cheese. However, production of such cheeses is a challenge, because fat has a pivotal role in structure and flavor of cheese $[30,34,61,62]$. Consumers perceive these products as different from their full-fat counterpart because excessively dry, firm or difficult to chew and with atypical flavor [26,29]. Burrata cheese popularity is growing, but it can contain up to $60 \%$ of fat [1]. Thus, the task of producing a reduced-fat Burrata is more challenging than for other cheeses. To our knowledge, in the only study aiming to develop a strategy for reducing fat in Burrata, partially skimmed milk and carob seeds suspension as fat replacer were combined, obtaining a reduced-fat Burrata cheese judged as having good sensory characteristics, but perceived different from the full-fat Burrata cheese [1]. This study used semi-skimmed milk, reduced-fat cream and two commercially available fat replacers, namely carrageenan and xanthan gums, alone or in combination with EPS-synthesizing lactic acid bacteria (LAB), to improve the sensory quality of reduced-fat Burrata cheese. Besides seven variants of reduced-fat cheese, a further reduced-fat Burrata, obtained by combining just semi-skimmed milk and reduced-fat cream, and a full-fat traditional Burrata (used as the control) were included in the experimental design. Burrata cheeses were manufactured at the same dairy plant, under the same biotic (house microbiota) and abiotic (e.g., acidification, stretching temperature, and salt concentration) selection pressures, which may affect cheese microbiota [63,64]. 
All of the reduced-fat Burrata cheeses were characterized by lower lipid concentration and higher moisture than the control, in agreement with previous studies $[1,39,65]$. The inverse correlation between lipid and moisture could be partly explained by the presence of xanthan, carrageenan or EPS putatively synthesized by the bacterial cultures (streptococci or lactococci or both) added in milk or cream. Indeed, these compounds act as fat replacers and, as such, they are able to bind water, thus resulting in higher moisture in cheese [65]. Post-acidification during storage occurred for the Burrata cheeses containing carrageenan (RCC) or xanthan (RCX) as fat replacers or produced by inoculating cream with a commercial EPS-synthesizing culture consisting of two strains of Lactococcus lactis (RCE2). This could be related to higher (order of magnitude: $8 \mathrm{log} \mathrm{cfu} / \mathrm{g}$ ) cell density of mesophilic cocci found in those cheeses after 16 days of storage. Mesophilic cocci (e.g., lactococci and Leuconostoc) also include psychrotrophic bacteria, which are able to keep on acidifying milk and dairy products during refrigerated storage [66,67]. It may be hypothesized that psychrotrophic mesophilic cocci, contributing to post-acidification of the Burrata cheeses analyzed in this study, belong to dairy house microbiota. Indeed, in a previous study on Burrata cheese, manufactured at the same dairy plant, Lc. lactis and Leuconostoc lactis were detected as components of the core microbiota of cheese, probably originating from cheese-making environment [4].

In this study, culture-dependent microbiological characterization of the Burrata cheeses showed that mesophilic and thermophilic cocci, although showing cheese variant-depending dynamics during storage, were dominant microbial groups. Presumptive Pseudomonas sp. flanked these two groups during storage, reaching cell densities higher than $6 \log \mathrm{CFU} \mathrm{g}^{-1}$. These results were in agreement with a previous study performed on Burrata in the same dairy plant [4]. Overall, mesophilic and thermophilic lactobacilli increased during storage and represented other dominant microbial groups, although with a cell density, on average, 1 log cycle lower than coccus-shaped LAB. This result was in contrast with the above-mentioned previous study, wherein rod-shaped LAB decreased during storage and belonged to sub-dominant microbiota [4]. In our experimental Burrata cheeses, sub-dominant cultivable microbiota was composed of enterococci, coliforms and yeasts.

Level of proteolysis showed little variations, depending on the Burrata cheese variant. However, overall proteins and peptides in the $\mathrm{pH}$ 4.6-soluble fraction increased during storage. As assessed through urea-PAGE and spectrophotometric determination, proteins in the $\mathrm{pH} 4.6$-insoluble fraction were subjected to limited hydrolysis during storage, in agreement with previous studies [1,4].

The panel test showed that the addition of the EPS-producing Streptococcus thermophilus in milk, in combination with either EPS-producing lactococci in cream (RCE1-2) or xanthan gum suspension (RCXE1), improved the overall acceptability of the Burrata cheeses. Even after 16 days of storage, RCE1-2 and RCXE1 were appreciated especially for their taste and texture. On the contrary, RCE2, RCX, RCC Burrata cheeses were judged as bitter and acid and with unpleasant aftertaste, being consistent with the post-acidification that characterized these cheeses. Therefore, bacterial microbiomes of RCE1-2 and RCXE1, as well as of the control and reduced-fat Burrata cheese not added with EPS-producing LAB and/or gums (RC), were described through 16S-targeted metagenomic analysis. A core microbiota, including S. thermophilus, Streptococcus lutetiensis, Lc. lactis, Lactococcus sp., Leuconostoc lactis, Lactobacillus delbrueckii, and Pseudomonas sp., characterized all of the Burrata cheeses, although with differences of relative abundance among the cheeses. S. thermophilus, used as starter E1 in the RCE1, RCE1-2, RCXE1, and RCCE1 Burrata cheeses, was one of the dominant OTUs in the control, RC, and RCE1-2 Burrata cheeses. Dominance of S. thermophilus in Burrata cheeses manufactured without starter E1 is probably due to contamination from dairy environment, in agreement with previous studies on cheeses manufactured at the same dairy plant used in this study $[4,68,69]$. Notwithstanding the high relative abundance of Pseudomonas sp. in three out of four Burrata cheeses, no defect, such as bitter taste and discoloration, was found at the end of storage. This could be explained by the species- and strain-specific spoilage ability by Pseudomonas sp. [70]. 
Multivariate statistical analysis showed that cell density of thermophilic lactobacilli could explain the distribution of Burrata cheeses. This bacterial group, with pro-technological role in fresh pasta filata cheese [71], was found in the RCE1-2 and RCXE1 at higher number $\left(6.8 \log\right.$ CFU g $\left.\mathrm{g}^{-1}\right)$ than control (4.3 $\log$ CFU g $\left.{ }^{-1}\right)$ and RC (5.8 $\log$ CFU g $\left.{ }^{-1}\right)$ Burrata cheeses. The positive correlation between $\mathrm{pH}$ and two coccus-shaped LAB OTU (Leuc. lactis and Streptococcus sp.) was in agreement with the results of culture-dependent analysis. Some positive correlations (e.g., Leuc. lactis, Lc. lactis, and Macrococcus caseolyticus) were in agreement with co-occurrence patterns observed for Caciotta cheese manufactured at the same dairy plant [69].

The consumer test indicated that more than $50 \%$ of consumers did not distinguish the traditional full-fat (control) from RCXE1 Burrata cheese. Fat concentration in the latter cheese was about 50\% lower than the control, allowing to label this product as "reduced-fat" [72]. After the two variants of Burrata cheese were disclosed to consumers, a majority of them preferred the control in terms of appearance, texture and odor. This is not so surprising, given that sensory tests are affected by several biases [73]. Although we used a non-forced choice preference testing, we may hypothesize that the variable "sample disclosure" probably affected consumers' preference, depending on the individual aptitude towards traditional or novel foods.

This study showed that the combination of semi-skimmed milk inoculated with EPS-synthesizing streptococci and reduced-fat cream diluted with xanthan gum suspension led to obtain a reduced-fat Burrata cheese with valuable sensory traits and very similar to the traditional full-fat counterpart.

Supplementary Materials: Supplementary materials can be found at http://www.mdpi.com/2076-2607/8/10/1618/ s1. Figure S1: Concentration of total peptides, determined after 1 (T1) and 16 (T16) days of storage at $4{ }^{\circ} \mathrm{C}$, in the $\mathrm{pH}$ 4.6-soluble fraction of Burrata cheeses made from whole milk and cream (Control); semi-skimmed milk and reduced-fat cream (RC); semi-skimmed milk and reduced-fat cream diluted with xanthan (RCX) or carrageenan (RCC); semi-skimmed milk added with exopolysaccharide producing starter E1 and reduced-fat cream (RCE1); semi-skimmed milk and reduced-fat cream added with exopolysaccharide producing starter E2 (RCE2); semi-skimmed milk and reduced-fat cream both added with E1 and E2 (RCE1-2); semi-skimmed milk added with E1 and reduced-fat cream diluted with xanthan (RCXE1) or carrageenan (RCCE1). Within the same sample, bars labelled with the same letter represent not significantly $(p>0.05)$ different values. Figure S2: Correlations based on microbiological (cell densities, OTU relative abundance) and biochemical (pH, TTA, concentrations of proteins in $\mathrm{pH}$ 4.6-soluble and -insoluble fraction, concentration of peptides in $\mathrm{pH}$ 4.6-soluble fraction) characteristics determined after 1 and 16 days of storage at $4{ }^{\circ} \mathrm{C}$ on the burrata cheeses made from: whole milk and cream (Control); semi-skimmed milk and reduced-fat cream (RC); semi-skimmed milk and reduced-fat cream both added with E1 and E2 (RCE1-2); semi-skimmed milk added with E1 and reduced-fat cream diluted with xanthan (RCXE1). The colors of the scale bar denote the nature of the correlation, with 1.00 indicating a perfectly positive correlation (red) and -1.00 indicating a perfectly negative correlation (green). Asterisk indicates significant correlations (FDR < 0.05). Table S1 Cheese-making ingredients used for the manufacturing of control and experimental (RC, RCX, RCC, RCE1, RCE2, RCE1-2, RCXE1, RCCE1) Burrata cheeses. Table S2 Average scores (from 1, lowest, to 5, highest) of sensory attributes resulting from the panel tests carried out on control and experimental (RC, RCX, RCC, RCE1, RCE2, RCE1-2, RCXE1, RCCE1) Burrata cheeses ${ }^{a}$ after 1 (T1), 8 (T8) and 16 (T16) days of storage at $4{ }^{\circ} \mathrm{C}$. Table S3 Relative abundance $(\%)^{a}$ of bacterial species found through $16 \mathrm{~S}$ metagenetic analysis of DNA extracted after 1 (T1) and 16 (T16) days of storage at $4{ }^{\circ} \mathrm{C}$, in the experimental Burrata cheeses $^{b}$.

Author Contributions: Conceptualization, M.D.A.; methodology, F.M. and M.D.A.; investigation and data curation; G.C. and M.C.; writing-original draft preparation, G.C. and F.M.; writing—review and editing, M.C., F.M. and M.D.A.; supervision, M.D.A.; project, administration, M.D.A.; funding acquisition, M.D.A. All authors have read and agreed to the published version of the manuscript.

Funding: This research was supported by Apulian Region Project (3QKDQX3) (Innovazione dei prodotti tradizionali pugliesi attraverso l'applicazione di strategie biotecnologiche al fine di avvicinarli alle esigenze dei consumatori in termini di caratteristiche organolettiche, salutistiche e nutrizionali-Innotipico).

Acknowledgments: We thank the industrial plant Ignalat, located in Noci, Bari (Apulia region), Italy, for experimental cheese-making trials.

Conflicts of Interest: The authors declare no conflict of interest. The funders had no role in the design of the study; in the collection, analyses, or interpretation of data; in the writing of the manuscript, or in the decision to publish the results. 


\section{References}

1. Trani, A.; Gambacorta, G.; Gomes, T.F.; Loizzo, P.; Cassone, A.; Faccia, M. Production and characterisation of reduced-fat and PUFA-enriched Burrata cheese. J. Dairy Res. 2016, 83, 236-241. [CrossRef]

2. Mipaaft. Diciannovesima Revisione dell'elenco dei Prodotti Agroalimentari Tradizionali. 2020. Available online: https://www.politicheagricole.it/flex/cm/pages/ServeBLOB.php/L/IT/IDPagina/13766 (accessed on 16 September 2020).

3. European Commission. Regulations: Commission Implementing Regulation (EU) 2016/2103. L 327/16. In Official Journal of the European Union; European Union: Brussels, Belgium, 2 December 2016. Available online: https:/eur-lex.europa.eu/legal-content/EN/TXT/PDF/?uri=OJ:L:2016:327:FULL\&from=SV (accessed on 20 September 2020).

4. Minervini, F.; Conte, A.; Del Nobile, M.A.; Gobbetti, M.; De Angelis, M. Dietary fibers and protective lactobacilli drive Burrata cheese microbiome. Appl. Environ. Microbiol. 2017, 83. [CrossRef]

5. Conte, A.; Brescia, I.; Del Nobile, M.A. Lysozyme/EDTA disodium salt and modified-atmosphere packaging to prolong the shelf life of Burrata cheese. J. Dairy Sci. 2011, 94, 5289-5297. [CrossRef]

6. Feeney, E.L.; Nugent, A.P.; Mc Nulty, B.; Walton, J.; Flynn, A.; Gibney, E.R. An overview of the contribution of dairy and cheese intakes to nutrient intakes in the Irish diet: Results from the National Adult Nutrition Survery. Br. J. Nutr. 2016, 115, 709-715. [CrossRef] [PubMed]

7. Gaucheron, F. Milk and dairy products: A unique micronutrient combination. J. Am. Coll. Nutr. 2011, 30, 400-409. [CrossRef] [PubMed]

8. Bates, B.; Lennox, A.; Prentice, A.; Bates, C.J. National Diet and Nutrition Survey: Results from Years 1-4 (Combined) of the Rolling Programme (2008/2009-2011/12); Public Health England: London, UK, 2014.

9. Fulgoni, V.L.; Keast, D.R.; Auestad, N.; Quann, E.E. Nutrients from dairy foods are difficult to replace in diets of Americans: Food pattern modeling and an analysis of the National Health and Nutrition Examination Survey 2003-2006. Nutr. Res. 2011, 31, 759-765. [CrossRef]

10. Iannotti, L.; Muehlhoff, E.; Mcmahon, D. Review of milk and dairy programmes affecting nutrition. J. Dev. Effect 2013, 5, 82-115. [CrossRef]

11. Hjerpsted, J.; Tholstrup, T. Cheese and cardiovascular disease risk: A review of the evidence and discussion of possible mechanisms. Crit. Rev. Food Sci. Nutr. 2015, 56, 1389-1403. [CrossRef]

12. Gulhane, M.; Murray, L.; Lourie, R.; Tong, H.; Sheng, Y.H.; Wang, R.; Kang, A.; Schreiber, V.; Wong, K.Y.; Magor, G.; et al. High fat diets induce colonic epithelial cell stress and inflammation that is reversed by IL-22. Sci. Rep. 2016, 6, 28990. [CrossRef]

13. Patterson, R.E.; Rock, C.L.; Kerr, J.; Natarajan, L.; Marshall, S.J.; Pakiz, B.; Cadmus-Bertram, L.A. Metabolism and breast cancer risk: Frontiers in research and practice. J. Acad. Nutr. Diet. 2013, 113, 288-296. [CrossRef]

14. Butler, L.M.; Wang, R.; Koh, W.P.; Stern, M.C.; Yuan, J.M.; Yu, M.C. Marine n-3 and saturated fatty acids in relation to risk of colorectal cancer in Singapore Chinese: A prospective study. Int. J. Cancer 2009, 124, 678-686. [CrossRef] [PubMed]

15. Arem, H.; Irwin, M.L. Obesity and endometrial cancer survival: A systematic review. Int. J. Obes. 2013, 37, 634-639. [CrossRef] [PubMed]

16. Thiebaut, A.C.M.; Kipnis, V.; Chang, S.C.; Subar, A.F.; Thompson, F.E.; Rosenberg, P.S.; Hollenbeck, A.R.; Leitzmann, M.; Schatzkin, A. Dietary fat and postmenopausal invasive breast cancer in the National Institutes of Health-AARP Diet and Health Study Cohort. JNCI J. Nat. Cancer I. 2007, 99, 451-462. [CrossRef]

17. Jansen, R.J.; Robinson, D.P.; Frank, R.D.; Anderson, K.E.; Bamlet, W.R.; Oberg, A.L.; Rabe, K.G.; Olson, J.E.; Sinha, R.; Petersen, G.M.; et al. Fatty acids found in dairy, protein and unsaturated fatty acids are associated with risk of pancreatic cancer in a case-control study. Int. J. Cancer 2013, 134, 1935-1946. [CrossRef] [PubMed]

18. Luck, H.; Tsai, S.; Chung, J.; Clemente-Casares, X.; Ghazarian, M.; Revelo, S.X.; Lei, H.; Luk, C.T.; Yu, S.S.; Surendra, A.; et al. Regulation of obesity-related insulin resistance with gut anti-inflammatory agents. Cell Metab. 2015, 21, 527. [CrossRef]

19. Martinez-Medina, M.; Denizot, J.; Dreux, N.; Robin, F.; Billard, E.; Bonnet, R.; Darfeuille-Michaud, A.; Barnich, N. Western diet induces dysbiosis with increased $E$. coli in CEABAC10 mice, alters host barrier function favouring AIEC colonisation. Gut 2014, 63, 116. [CrossRef] 
20. Cani, P.D.; Bibiloni, R.; Knauf, C.; Waget, A.; Neyrinck, M.; Delzenne, N.M.; Burcelin, R. Changes in gut microbiota control metabolic endotoxemia-induced inflammation in high-fat diet-induced obesity and diabetes in mice. Diabetes 2008, 57, 1470. [CrossRef]

21. Crean, A.J.; Senior, A.M. High-fat diets reduce male reproductive success in animal models: A systematic review and meta-analysis. Obes. Rev. 2019, 20, 921-933. [CrossRef]

22. Song, M.; Garrett, W.S.; Chan, A.T. Nutrients, foods, and colorectal cancer prevention. Gastroenterology 2015, 148, 1244-1260. [CrossRef]

23. McDonald, B.E. Dietary cholesterol: Is there a problem? In IDF Bullettin; International Dairy Federation: Brussels, Belgium, 2000; Volume 355, pp. 22-24.

24. León-Muñoz, L.M.; Guallar-Castillón, P.; Graciani, A.; López-García, E.; Mesas, A.E.; Aguilera, M.T.; Banegas, J.R.; Rodríguez-Artalejo, F. Adherence to the Mediterranean diet pattern has declined in Spanish adults. J. Nutr. 2012, 142, 1843-1850. [CrossRef]

25. Drake, M.A.; Swanson, B.G. Reduced and low-fat cheese technology: A review. Trends Food Sci. Technol. 1995, 6, 366-369. [CrossRef]

26. Banks, J.M. The technology of low-fat cheese manufacture. Int. J. Dairy Technol. 2004, 57, 199-207. [CrossRef]

27. Juan, B.; Zamora, A.; Quintana, F.; Guamis, B.; Trujillo, A.J. Effect of inulin addition on the sensorial properties of reduced-fat fresh cheese. Int. J. Dairy Technol. 2013, 66, 478-483. [CrossRef]

28. Koca, N.; Metin, M. Textural, melting and sensory properties of low-fat fresh Kashar cheeses produced by using fat replacers. Int. Dairy J. 2004, 14, 365-373. [CrossRef]

29. Costa, N.E.; O'Callaghan, D.J.; Mateo, M.J.; Chaurin, V.; Castillo, M.; Hannon, J.A.; McSweeney, P.L.H.; Beresford, T.P. Influence of an exopolysaccharide produced by a starter on milk coagulation and curd syneresis. Int. Dairy J. 2011, 22, 48-57. [CrossRef]

30. Sánchez-Macías, D.; Fresno, M.; Moreno-Indias, I.; Castro, N.; Morales-delaNuez, A.; Álvarez, S.; Argüello, A. Physicochemical analysis of full-fat, reduced-fat, and low-fat artisan-style goat cheese1. J. Dairy Sci. 2010, 93, 3950-3956. [CrossRef]

31. Jameson, G.W. Dietary cheeses: Low fat, low salt. Food Technol. Aust. 1987, 39, 99-101.

32. McGregor, J.U.; White, C.H. Effect of enzyme treatment and ultrafiltration on the quality of low-fat Cheddar cheese. J. Dairy Sci. 1990, 73, 571-578. [CrossRef]

33. Mistry, V.V.; Metzger, L.E.; Maubois, J.L. Use of ultrafiltered sweet buttermilk in the manufacture of reduced fat Cheddar cheese. J. Dairy Sci. 1996, 79, 1137-1145. [CrossRef]

34. Mistry, V.V. Low-fat cheese technology. Int. Dairy J. 2001, 11, 413-422. [CrossRef]

35. Li, H.; Yu, H.; Liu, Y.; Wang, Y.; Li, H.; Yu, J. The use of inulin, maltitol and lecithin as fat replacers and plasticizers in a model reduced fat mozzarella cheese like product. J. Sci. Food Agric. 2019, 99, 5586-5593. [CrossRef]

36. Khanal, B.K.S.; Bhandari, B.; Prakash, S.; Liu, D.; Zhou, P.; Bansal, N. Modifying textural and microstructural properties of low-fat Cheddar cheese using sodium alginate. Food Hydrocoll. 2018, 83, 97-108. [CrossRef]

37. Wang, J.; Wu, T.; Fang, X.; Yang, Z. Manufacture of low-fat Cheddar cheese by exopolysaccharide-producing Lactobacillus plantarum JLK0142 and its functional properties. J. Dairy Sci. 2019, 102, 3825-3838. [CrossRef] [PubMed]

38. Oberg, E.N.; Oberg, C.J.; Motawee, M.M.; Martini, S.; McMahon, D.J. Increasing stringiness of low-fat mozzarella string cheese using polysaccharides. J. Dairy Sci. 2015, 98, 4243-4254. [CrossRef] [PubMed]

39. Di Cagno, R.; De Pasquale, I.; De Angelis, M.; Buchin, S.; Rizzello, C.G.; Gobbetti, M. Use of microparticulated whey protein concentrate, exopolysaccharide-producing Streptococcus thermophilus, and adjunct cultures for making low-fat Italian Caciotta-type cheese. J. Dairy Sci. 2014, 97, 72-84. [CrossRef] [PubMed]

40. Baldini, M.; Fabietti, F.; Giammarioli, S.; Onori, R.; Orefice, L.; Stacchini, A. Metodi di Analisi Utilizzati per il Controllo Chimico Degli Alimenti; Rapporti ISTISAN 96/34; Rapporti ISTISAN: Roma, Italy, 1996.

41. ISO. ISO 3433 Cheese-Determination of Fat Content_Van Gulik Method; International Organization for Standardization; ISO: Geneva, Switzerland, 2008.

42. Kuchroo, C.N.; Fox, P.F. Soluble nitrogen in Cheddar cheese: Comparison of extraction procedures. Milchwissenschaft 1982, 37, 331-335.

43. Andrews, A.T.; Alichanidis, E. Proteolysis of caseins and the proteose-peptone fraction of bovine milk. J. Dairy Res. 1983, 50, 275-290. [CrossRef] 
44. Blakesley, R.W.; Boezi, J.A. A new staining technique for proteins in polyacrylamide gels using Coomassie brilliant blue G250. Anal. Biochem. 1977, 82, 580-582. [CrossRef]

45. Bradford, M.M. A rapid and sensitive method for the quantitation of microgram quantities of protein utilizing the principle of protein-dye binding. Anal. Biochem. 1976, 72, 248-254. [CrossRef]

46. Church, F.C.; Swaisgood, H.E.; Porter, D.H.; Catignani, G.L. Spectrophotometric assay using o-phthaldialdehyde for determination of proteolysis in milk and isolated milk proteins. J. Dairy Sci. 1983, 66, 1219-1227. [CrossRef]

47. Minervini, F.; Siragusa, S.; Faccia, M.; Dal Bello, F.; Gobbetti, M.; De Angelis, M. Manufacture of fior di latte cheese by incorporation of probiotic lactobacilli. J. Dairy Sci. 2012, 95, 508-520. [CrossRef]

48. Coppola, S.; Villani, F.; Coppola, R.; Parente, E. Comparison of different starter systems for water-buffalo mozzarella cheese manufacture. Lait 1990, 70, 411-423. [CrossRef]

49. De Angelis, M.; de Candia, S.; Calasso, M.P.; Faccia, M.; Guinee, T.P.; Simonetti, M.C.; Gobbetti, M. Selection and use of autochthonous multiple strain cultures for the manufacture of high-moisture traditional mozzarella cheese. Int. J. Food Microbiol. 2008, 125, 123-132. [CrossRef] [PubMed]

50. ISO Sensory Analysis. General Guidance for the Design of Test Rooms; ISO 8589; International Organization of Standardization: Geneva, Switzerland, 1988.

51. Handl, S.; Dowd, S.E.; Garcia-Mazcorro, J.F.; Steiner, J.M.; Suchodolski, J.S. Massive parallel 16S rRNA gene pyrosequencing reveals highly diverse fecal bacterial and fungal communities in healthy dogs and cats. FEMS Microbiol. Ecol. 2011, 76, 301-310. [CrossRef] [PubMed]

52. Rhoads, D.D.; Wolcott, R.D.; Sun, Y.; Dowd, S.E. Comparison of culture and molecular identification of bacteria in chronic wounds. Int. J. Mol. Sci. 2012, 13, 2535-2550. [CrossRef] [PubMed]

53. Edgar, R.C.; Haas, B.J.; Clemente, J.C.; Quince, C.; Knight, R. UCHIME improves sensitivity and speed of chimera detection. Bioinformatics 2011, 27, 2194-2200. [CrossRef] [PubMed]

54. Edgar, R.C. Search and clustering orders of magnitude faster than BLAST. Bioinformatics 2010, 26, $2460-2461$. [CrossRef] [PubMed]

55. Andreotti, R.; Pérez de León, A.; Dowd, S.E.; Guerrero, F.D.; Bendele, K.G.; Scoles, G. Assessment of bacterial diversity in the cattle tick Rhipicephalus (Boophilus) microplus through tag-encoded pyrosequencing. BMC Microbiol. 2011, 11. [CrossRef]

56. Hooper, L.; Martin, N.; Abdelhamid, A.; Davey, S.G. Reduction in saturated fat intake for cardiovascular disease. Cochrane Database Syst. Rev. 2015. [CrossRef]

57. World Health Organization. Diet, Nutrition and the Prevention of Chronic Diseases: Report of a Joint WHO/FAO Expert Consultation; World Health Organization: Geneva, Switzerland, 2003. Available online: https: //www.who.int/dietphysicalactivity/publications/trs916/en/ (accessed on 20 September 2020).

58. Food and Agriculture Organization. Fats and Fatty Acids in Human Nutrition: Report of an Expert Consultation; Food and Agriculture Organization of the United Nations: Rome, Italy, 2010. Available online: https://www. who.int/nutrition/publications/nutrientrequirements/fatsandfattyacids_humannutrition/en/ (accessed on 20 September 2020).

59. Bimbo, F.; Bonanno, A.; Nocella, G.; Viscecchia, R.; Nardone, G.; De Devitiis, B.; Carlucci, D. Consumers' acceptance and preferences for nutrition-modified and functional dairy products: A systematic review. Appetite 2017, 113, 141-154. [CrossRef]

60. Henneberry, S.; O'Sullivan, M.G.; Kilcawley, K.N.; Kelly, P.M.; Wilkinson, M.G.; Guinee, T.P. Sensory quality of unheated and heated Mozzarella-style cheeses with different fat, salt and calcium levels. Int. J. Dairy Technol. 2016, 69, 38-50. [CrossRef]

61. Rogers, N.; McMahon, D.J.; Daubert, C.R.; Berry, T.; Foegeding, E.A. Rheological properties and microstructure of Cheddar cheese made with different fat contents. J. Dairy Sci. 2010, 93, 4565-4576. [CrossRef] [PubMed]

62. Zisu, B. Impact of Preacidification, Fat Replacers and Exopolysaccharide Producing Starter Cultures on Functionality of Low-Fat Mozzarella Cheese. Ph.D. Thesis, Victoria University, Victoria, Australia, 2005. Available online: http://vuir.vu.edu.au/16090/3/ZISU\%20Bogdan-thesis_nosignature.pdf (accessed on 20 September 2020).

63. Gobbetti, M.; Di Cagno, R.; Calasso, M.; Neviani, E.; Fox, P.F.; De Angelis, M. Drivers that establish and assemble the lactic acid bacteria biota in cheeses. Trends Food Sci. Technol. 2018, 78, 244-254. [CrossRef]

64. Kamimura, B.A.; De Filippis, F.; Sant'Ana, A.S.; Ercolini, D. Large-scale mapping of microbial diversity in artisanal Brazilian cheeses. Food Microbiol. 2019, 80, 40-49. [CrossRef] [PubMed] 
65. Kavas, G.; Oysun, G.; Kinik, O.; Uysal, H. Effect of some fat replacers on chemical, physical and sensory attributes of low-fat white pickled cheese. Food Chem. 2004, 88, 381-388. [CrossRef]

66. Oliveira, M.M.; Almeida, K.E.; Damin, M.R.; Rochat, T.; Gratadoux, J.J.; Miyoshi, A.; Langella, P.; Azevedo, V. Behavior and viability of spontaneous oxidative stress-resistant Lactococcus lactis mutants in experimental fermented milk processing. Genet. Mol. Res. 2009, 8, 840-847. [CrossRef]

67. Kives, J.; Guadarrama, D.; Orgaz, B.; Rivera-Sen, A.; Vazquez, J.; SanJose, C. Interactions in biofilms of Lactococcus lactis ssp. cremoris and Pseudomonas fluorescens cultured in cold UHT milk. J. Dairy Sci. 2005, 88, 4165-4171. [CrossRef]

68. Calasso, M.; Ercolini, D.; Mancini, L.; Stellato, G.; Minervini, F.; Di Cagno, R.; De Angelis, M.; Gobbetti, M. Relationships among house, rind and core microbiotas during manufacture of traditional Italian cheeses at the same dairy plant. Food Microbiol. 2016, 54, 115-126. [CrossRef]

69. Calasso, M.; Minervini, F.; De Filippis, F.; Ercolini, D.; De Angelis, M.; Gobbetti, M. Attenuated Lactococcus lactis and surface bacteria as tools for conditioning the microbiota and driving the ripening of semisoft Caciotta cheese. Appl. Environ. Microbiol. 2019, 86, e02165-19. [CrossRef]

70. Carminati, D.; Bonvini, B.; Rossetti, L.; Zago, M.; Tidona, F.; Giraffa, G. Investigation on the presence of blue pigment-producing Pseudomonas strains along a production line of fresh mozzarella cheese. Food Control 2019, 100, 321-328. [CrossRef]

71. Marino, M.; Dubsky de Wittenau, G.; Saccà, E.; Cattonaro, F.; Spadotto, A.; Innocente, N.; Radovic, S.; Piasentier, E.; Marroni, F. Metagenomic profiles of different types of Italian high-moisture Mozzarella cheese. Food Microbiol. 2019, 79, 123-131. [CrossRef] [PubMed]

72. Food Labeling: General Requirements for Health Claims for Food. Federal Register 1993, 58, $2478-2536$.

73. Drake, M.A. Modern sensory practices. In The Sensory Evaluation of Dairy Products; Clark, S., Costello, M., Drake, M.A., Bodyfelt, F., Eds.; Springer: New York, NY, USA, 2009; pp. 505-530.

Publisher's Note: MDPI stays neutral with regard to jurisdictional claims in published maps and institutional affiliations.

(C) 2020 by the authors. Licensee MDPI, Basel, Switzerland. This article is an open access article distributed under the terms and conditions of the Creative Commons Attribution (CC BY) license (http://creativecommons.org/licenses/by/4.0/). 